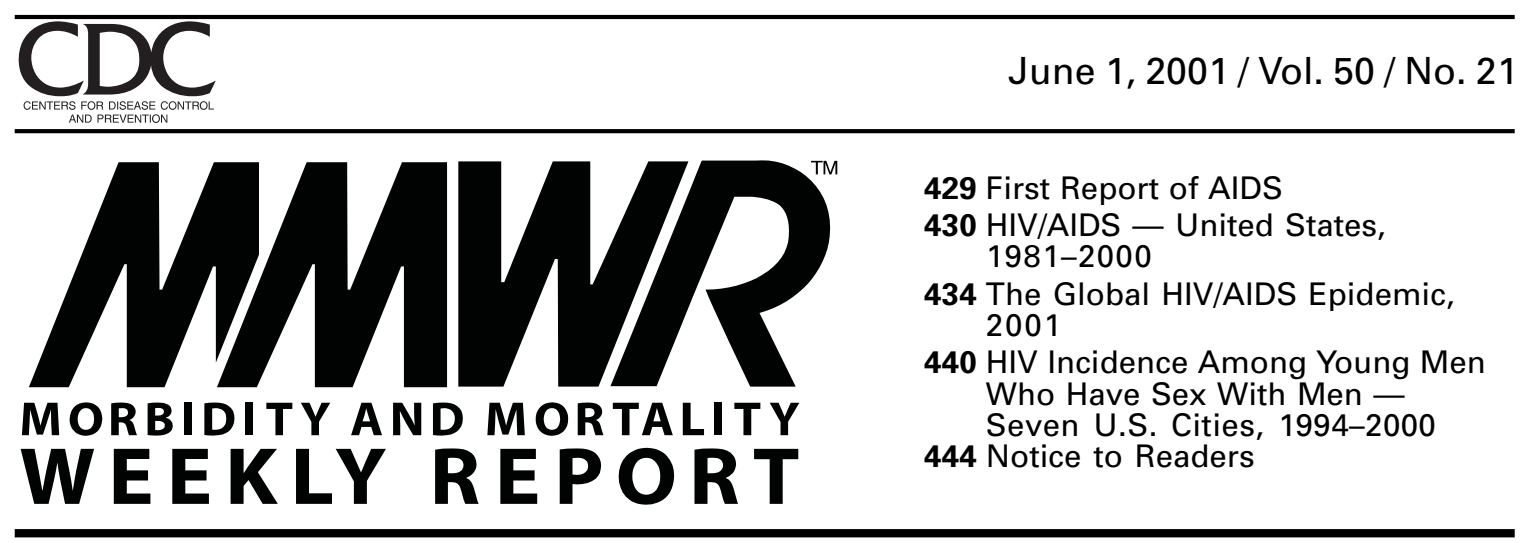

\title{
First Report of AIDS
}

Twenty years ago, on June 5, 1981, MMWR published a report of five cases of Pneumocystis carinii pneumonia (PCP) among previously healthy young men in Los Angeles (1). All of the men were described as "homosexuals"; two had died. Local clinicians and the Epidemic Intelligence Service (EIS) Officer stationed at the Los Angeles County Department of Public Health, prepared the report and submitted it for $M M W R$ publication in early May 1981. Before publication, MMWR editorial staff sent the submission to CDC experts in parasitic and sexually transmitted diseases. The editorial note that accompanied the published report stated that the case histories suggested a "cellular-immune dysfunction related to a common exposure" and a "disease acquired through sexual contact." The report prompted additional case reports from New York City, San Francisco, and other cities. At about the same time, CDC's investigation drug unit, the sole distributor of pentamidine, the therapy for PCP, began to receive requests for the drug from physicians also to treat young men. In June 1981, CDC developed an investigative team to identify risk factors and to develop a case definition for national surveillance. Within 18 months, epidemiologists conducted studies and prepared $M M W R$ reports that identified all of the major risks factors for acquired immnodeficiency syndrome (AIDS). In March 1983, CDC issued recommendations for prevention of sexual, drug-related, and occupational transmission based on these early epidemiologic studies and before the cause of the new, unexplained illness was known.

MMWR has published more than 400 reports about human immunodeficiency virus (HIV) and AIDS and remains a primary source of information about the epidemiology, surveillance, prevention, care, and treatment of HIV and AIDS. This anniversary issue provides new reports on the epidemiologic features and impact of HIV/ AIDS on communities in the United States and in other countries. A compilation of notable MMWR reports on HIV and AIDS is available at http://www.cdc.gov/mmwr/ hiv_aids20.html. A video that includes interviews with participants in these first AIDS investigations and reports and a video summary of each report in this issue is available at http://www.cdc.gov/mmwr.

Reference

1. CDC. Pneumocystis pneumonia - Los Angeles. MMWR 1981;30:250-2. 


\section{HIV and AIDS — United States, 1981-2000}

The acquired immunodeficiency syndrome (AIDS) epidemic has had a substantial impact on the health and economy of many nations (1). Since the first AIDS cases were reported in the United States in June 1981, the number of cases and deaths among persons with AIDS increased rapidly during the 1980s followed by substantial declines in new cases and deaths in the late 1990s. This report describes the changes in the characteristics of persons with AIDS since 1981. The greatest impact of the epidemic is among men who have sex with men (MSM) and among racial/ethnic minorities, with increases in the number of cases among women and of cases attributed to heterosexual transmission. The number of persons living with AIDS has increased as deaths have declined. Controlling the epidemic requires sustained prevention programs in all of these affected communities, particularly programs targeting MSM, women, and injection drug users.

CDC analyzed reported AIDS cases from 1981 through 2000 from the 50 states, District of Columbia, and U.S. territories. Proportions by sex, age, race/ethnicity, region, and vital status (living or deceased) were computed over four time periods corresponding to changes in the AIDS case definition and the introduction of effective combination antiretroviral therapy (Table 1). Trends in estimated AIDS diagnoses and deaths of persons with AIDS were adjusted for reporting delays based on the number of cases reported to CDC through June 2000, and for anticipated reclassification of cases originally reported without human immunodeficiency virus (HIV) infection risk information. Estimated AIDS prevalence was calculated as the cumulative incidence of AIDS minus cumulative deaths adjusted for reporting delays (2).

As of December 31, 2000, 774,467 persons had been reported with AIDS in the United States; 448,060 of these had died; 3542 persons had unknown vital status. The number of persons living with AIDS $(322,865)$ is the highest ever reported. Of these, $79 \%$ were men, $61 \%$ were black or Hispanic, and $41 \%$ were infected through male-to-male sex. Of the AIDS cases, approximately one third were reported during 1981-1992, 19931995, and 1996-2000 (Table 1).

AIDS incidence increased rapidly through the 1980s, peaked in the early 1990s, and then declined (Figure 1). The peak of new diagnoses was associated with the expansion of the AIDS surveillance case definition in 1993 (2). As of 1996, sharp declines were reported in AIDS incidence and deaths. From 1998 through June 2000, AIDS incidence and deaths leveled off and AIDS prevalence continued to increase. Throughout the epidemic, approximately $85 \%$ of persons diagnosed with AIDS were aged 20-49 years (Table 1).

In the early 1980s, most AIDS cases occurred among whites. However, cases among blacks increased steadily and by 1996, more cases occurred among blacks than any other racial/ethnic population. Cases among Hispanics, Asians/Pacific Islanders, and American Indians/Alaska Natives have increased also (Table 1).

Male-to-male sex has been the most common mode of exposure among persons reported with AIDS (46\%), followed by injection drug use (25\%) and heterosexual contact $(11 \%)$. The incidence of AIDS increased rapidly in all three of these risk categories through the mid-1990s; however, since 1996, declines in new AIDS cases have been higher among MSM and injection drug users than among persons exposed through heterosexual contact (Figure 2). 
HIV and AIDS in the United States - Continued

TABLE 1. Number and percentage of persons with AIDS, by selected characteristics and period of report - United States, 1981-2000

\begin{tabular}{|c|c|c|c|c|c|c|c|c|}
\hline \multirow[b]{2}{*}{ Characteristic } & \multicolumn{2}{|c|}{ 1981-1987 } & \multicolumn{2}{|c|}{ 1988-1992 } & \multicolumn{2}{|c|}{ 1993-1995 } & \multicolumn{2}{|c|}{$1996-2000$} \\
\hline & No. & $(\%)$ & No. & $(\%)$ & No. & $(\%)$ & No. & $(\%)$ \\
\hline \multicolumn{9}{|l|}{ Sex } \\
\hline Male & 46,251 & (92.0) & 177,132 & (87.5) & 211,909 & (82.4) & 204,730 & (77.4) \\
\hline Female & 4,029 & $(8.0)$ & 25,387 & (12.5) & 45,353 & (17.6) & 59,672 & (22.6) \\
\hline \multicolumn{9}{|l|}{ Age group (yrs) } \\
\hline $0-4$ & 649 & $(1.3)$ & 2,763 & ( 1.4$)$ & 2,105 & $(0.8)$ & 1,355 & $(0.5)$ \\
\hline $5-12$ & 101 & $(0.2)$ & 667 & $(0.3)$ & 650 & $(0.3)$ & 618 & $(0.2)$ \\
\hline $13-19$ & 199 & $(0.4)$ & 759 & $(0.4)$ & 1,381 & $(0.5)$ & 1,722 & $(0.7)$ \\
\hline $20-29$ & 10,523 & (20.9) & 38,507 & $(19.0)$ & 43,445 & (16.9) & 36,252 & (13.7) \\
\hline $30-39$ & 23,239 & (46.2) & 92,178 & (45.5) & 116,335 & (45.2) & 114,072 & (43.1) \\
\hline $40-49$ & 10,472 & (20.8) & 46,922 & (23.2) & 67,475 & $(26.2)$ & 78,032 & (29.5) \\
\hline $50-59$ & 3,684 & $(7.3)$ & 14,494 & $(7.2)$ & 19,153 & $(7.4)$ & 23,980 & $(9.1)$ \\
\hline$\geq 60$ & 1,413 & ( 2.8$)$ & 6,230 & (3.1) & 6,718 & ( 2.6$)$ & 8,373 & (3.2) \\
\hline \multicolumn{9}{|l|}{ Race/Ethnicity } \\
\hline $\begin{array}{l}\text { White, } \\
\text { non-Hispanic }\end{array}$ & 30,033 & (59.7) & 102,130 & $(50.4)$ & 109,101 & $(42.4)$ & 88,896 & $(34.0)$ \\
\hline $\begin{array}{l}\text { Black, } \\
\text { non-Hispanic }\end{array}$ & 12,796 & (25.5) & 63,319 & (31.2) & 97,742 & $(38.0)$ & 118,665 & (44.9) \\
\hline Hispanic* & 7,044 & (14.0) & 35,116 & (17.3) & 47,442 & (18.4) & 52,092 & (19.7) \\
\hline $\begin{array}{l}\text { Asian/Pacific } \\
\text { Islander }\end{array}$ & 312 & $(0.6)$ & 1,342 & $(0.7)$ & 1,927 & $(0.8)$ & 2,147 & $(0.8)$ \\
\hline American India & & & & & & & & \\
\hline Alaska Native & 68 & $(0.1)$ & 437 & $(0.2)$ & 870 & $(0.3)$ & 962 & $(0.4)$ \\
\hline \multicolumn{9}{|l|}{ Region $^{\dagger}$} \\
\hline Northeast & 19,541 & (38.9) & 62,102 & $(30.7)$ & 78,000 & (30.3) & 81,466 & (30.8) \\
\hline North Central & 3,772 & $(7.5)$ & 20,416 & $(10.1)$ & 25,778 & $(10.0)$ & 25,532 & (9.7) \\
\hline South & 12,933 & (25.7) & 65,754 & (32.5) & 89,559 & (34.8) & 102,576 & (38.8) \\
\hline West & 13,502 & (26.9) & 46,303 & (22.9) & 55,586 & (21.6) & 45,574 & (17.2) \\
\hline U.S. territories & 524 & $(1.0)$ & 7,883 & ( 3.9$)$ & 8,812 & $(3.2)$ & 8,829 & (3.3) \\
\hline \multicolumn{9}{|l|}{ Vital status } \\
\hline Living & 2,103 & $(4.2)$ & 20,572 & $(10.2)$ & 96,998 & (37.7) & 203,192 & (76.9) \\
\hline Deceased & 47,993 & (95.5) & 181,212 & (89.5) & 159,048 & (61.8) & 59,807 & (22.6) \\
\hline Total $\left.\right|^{\S}$ & 50,280 & (6.5) & 202,520 & (26.2) & 257,262 & (33.2) & 264,405 & (34.1) \\
\hline
\end{tabular}

* Persons of Hispanic origin may be of any race.

${ }^{\dagger}$ Northeast=Connecticut, Maine, Massachusetts, New Hampshire, New Jersey, New York, Pennsylvania, Rhode Island, and Vermont; North Central=Illinois, Indiana, lowa, Kansas, Michigan, Minnesota, Missouri, Nebraska, North Dakota, Ohio, South Dakota, and Wisconsin; South=Alabama, Arkansas, Delaware, District of Columbia, Florida, Georgia, Kentucky, Louisiana, Maryland, Mississippi, North Carolina, Oklahoma, South Carolina, Tennessee, Texas, Virginia, and West Virginia; West=Alaska, Arizona, California, Colorado, Hawaii, Idaho, Montana, Nevada, New Mexico, Oregon, Utah, Washington, and Wyoming.

${ }^{\S}$ Includes persons for whom sex, age, race/ethnicity, region, or vital status are missing. 
HIV and AIDS in the United States - Continued

FIGURE 1. Estimated AIDS incidence*, deaths, and prevalence, by quarter-year of diagnosis/death — United States, 1981-2000

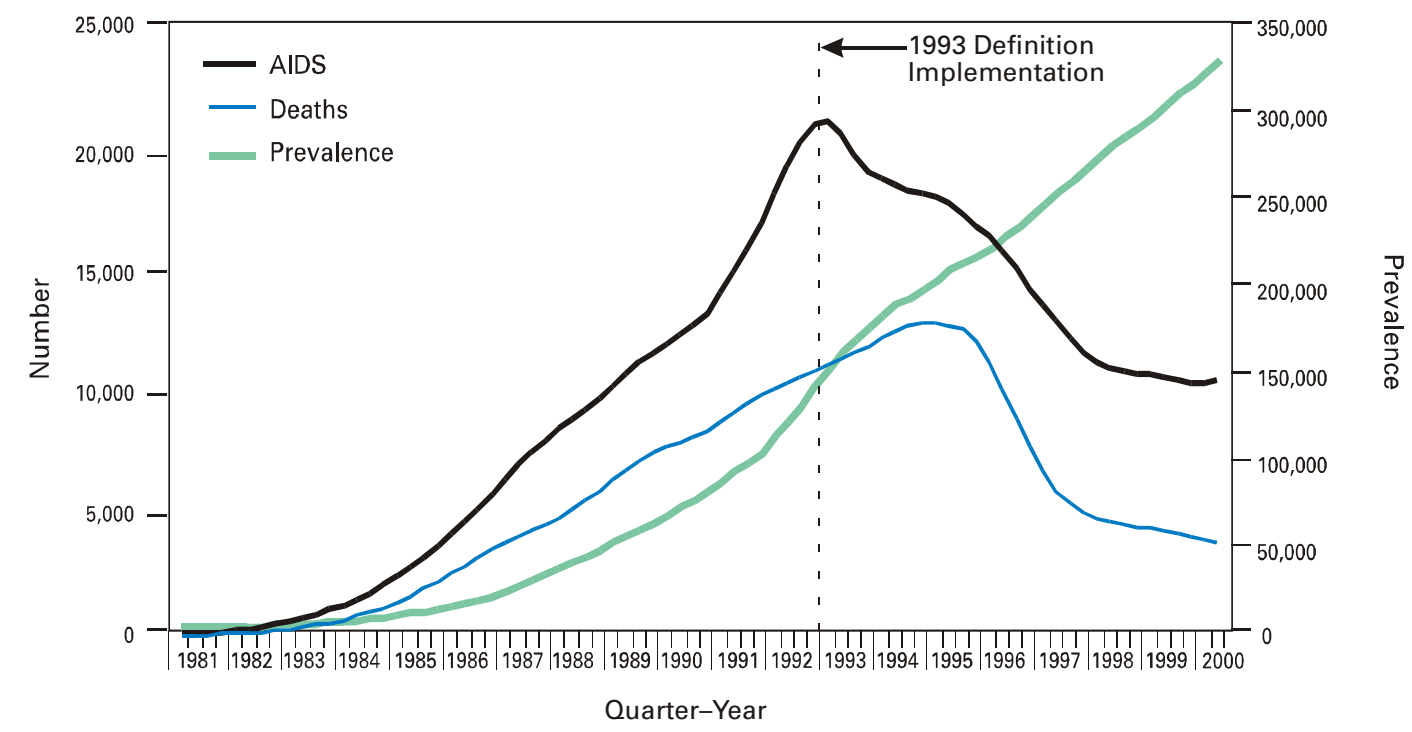

* Adjusted for reporting delays.

FIGURE 2. Number of AIDS cases among men who have sex with men (MSM), injection drug users (IDU), and persons exposed through heterosexual contact, by quarter-year of diagnosis - United States, 1981-2000

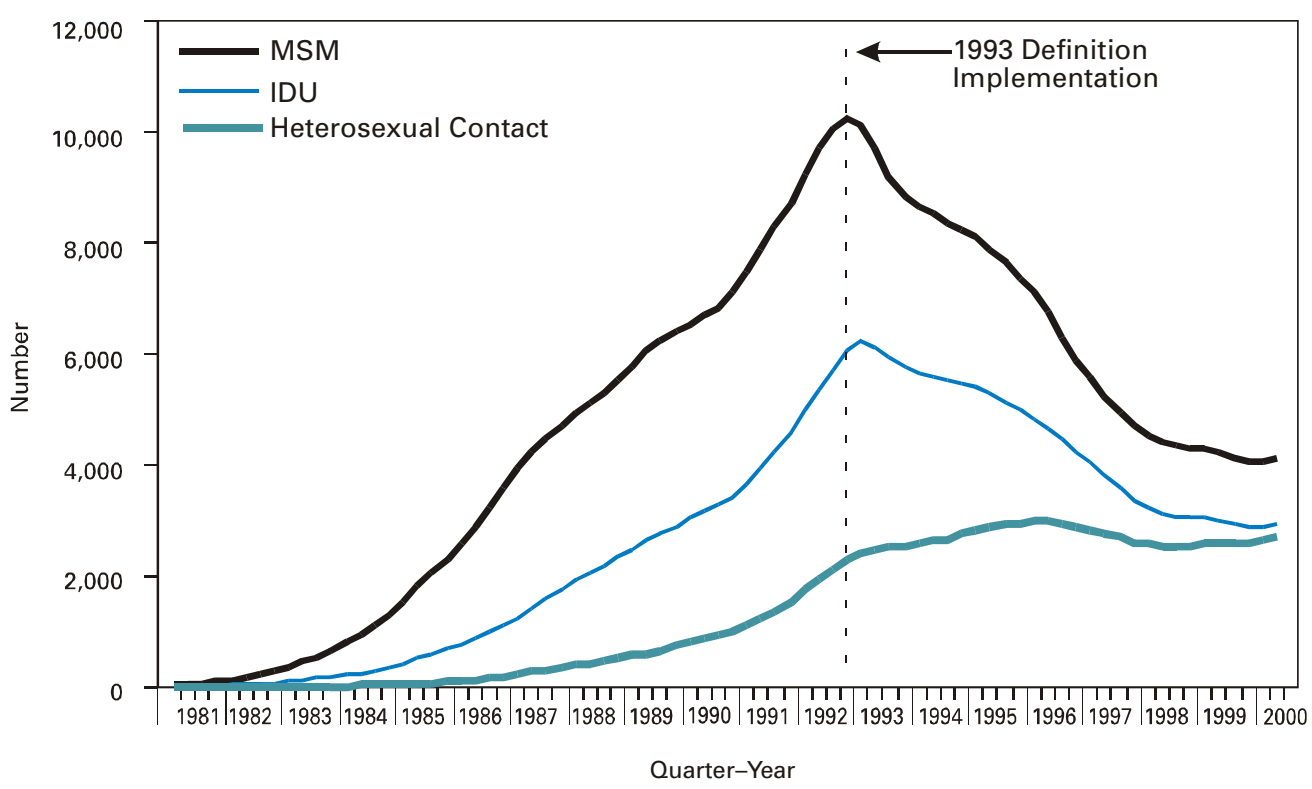


HIV and AIDS in the United States - Continued

Nearly all transmission of HIV through transfusion of blood or blood products occurred before screening of the blood supply for HIV antibody was initiated in 1985 (3). The number of persons reported with AIDS who were exposed through blood transfusions was 284 in 2000, down from a peak of 1098 in 1993. The number of perinatally acquired AIDS cases peaked in 1992 (901 cases), followed by a sharp decline through December 1999. In 1999, 144 cases of perinatally acquired AIDS were diagnosed.

Reported by: Surveillance Br, Div of HIV/AIDS Prevention, National Center for HIV, STD, and TB Prevention, CDC.

Editorial Note: AIDS in the United States remains primarily an epidemic affecting MSM and racial/ethnic minorities. A new generation of MSM has replaced those who benefitted from early prevention strategies, and minority MSM have emerged as the population most affected by HIV. Socioeconomic factors (e.g., homophobia, high rates of poverty and unemployment, and lack of access to health care) are associated with high rates of HIV risk behaviors among minority MSM and are barriers to accessing HIV testing, diagnosis, and treatment (4). Minority MSM may not identify themselves as homosexual or bisexual because of the stigma attached to these activities and may be difficult to reach with HIV prevention messages. In addition, the proportion of AIDS cases attributed to heterosexual contact and among women is substantially greater than earlier in the epidemic.

Several public health successes have been achieved during the AIDS epidemic. Disease-monitoring systems were established following the first reports in 1981 (5). Data from these systems helped determine how AIDS was transmitted and provided a basis for the Public Health Service (PHS) to make prevention recommendations. The licensure of a blood test to screen the nation's blood supply and donor and self-deferral measures dramatically reduced the incidence of transfusion-associated HIV infections (6). Less than one in 450,000-660,000 screened blood donations are estimated to be contaminated with HIV (7).

In 1985, the first federal resources dedicated to HIV prevention were made available to all state and local health departments nationwide. In 1987, a national effort to educate the public about HIV and AIDS was launched and CDC created a comprehensive AIDS information resource, the CDC National AIDS Hotline and National AIDS Information Clearinghouse. Comprehensive school-based HIV education to inform and educate young persons began in 1987, and funding for national, regional, and community-based organizations began in 1988 .

The first research on effective behavior interventions to reduce transmission of HIV among sex partners and injection drug users began in the early 1980s. Behavior interventions, including school-based programs, peer-to-peer interventions, strategies that limit needle sharing, strategies that use parent-to-child communication, client-centered counseling, and personalized risk-reduction strategies, are effective in promoting healthy behaviors that are protective for HIV (8).

PHS released guidelines in 1994 and 1995 for routinely counseling and voluntarily testing pregnant women for HIV and for offering zidovudine to infected women and their infants (9). Since this intervention, mother-to-child HIV transmission rates have decreased dramatically. During 1985-1999, AIDS cases among children declined 81\%.

As a result of these and other HIV prevention efforts and increases in societal awareness of and response to the AIDS epidemic, new infections in the United States, which had risen rapidly to a peak of 150,000 per year in the mid-1980s, declined to an estimated 
HIV and AIDS in the United States - Continued

40,000 per year since 1992 . With the advent of highly active antiretroviral therapy in the mid-1990s, the number of new AIDS cases and deaths declined dramatically and then stabilized in the United States and several other industrialized nations.

Despite the decline in HIV-related disease and death in the United States, major gaps exist in the tools needed to address HIV prevention. The development of an HIV vaccine is important to control the global epidemic. Development of a microbicide that is safe and effective in reducing HIV transmission through sexual intercourse may be key to controlling the epidemic among women. New behavior interventions, particularly targeting minority MSM, are needed.

Political, financial, and social barriers have often kept the most effective prevention and treatment strategies from reaching those at highest risk. In addition, HIV-related stigma continues to hinder prevention, testing, and treatment. Expanding HIV prevention programs remains an urgent priority in the United States. Reaching populations at risk to ensure early diagnosis and ensuring sustained access to preventive and treatment services for all at risk and HIV-infected persons can have a major impact on the HIV and AIDS epidemic (10).

References

1. World Health Organization/UNAIDS. AIDS epidemic update. Geneva, Switzerland: World Health Organization, December 2000.

2. CDC. HIV/AIDS surveillance report, 2000;12(no. 1).

3. CDC. Provisional Public Health Service interagency recommendations for screening donated blood and plasma for antibody to the virus causing acquired immunodeficiency syndrome. MMWR 1985;34:1-5.

4. CDC. HIV/AIDS among racial/ethnic minority men who have sex with men-United States, 1989-1998. MMWR 2000;49:4-11.

5. Valdiserri RO, Janssen RS, Buehler JW, Fleming PL. The context of HIV/AIDS surveillance. J Acquir Immune Defic Syndr Hum Retroviral 2000;25:S97-S104.

6. Selik RM, Ward JW, Buehler JW. Trends in transfusion-associated acquired immune deficiency syndrome in the United States, 1982-1991. Transfusion 1993;33:890-3.

7. Lackritz EM, Satten GA, Aborle-Grasse J, et al. Estimated risk of transmission of the human immunodeficiency virus by screened blood in the United States. N Engl J Med 1995;333:1721-5.

8. CDC. Compendium of HIV prevention interventions with evidence of effectiveness. Atlanta, Georgia: US Department of Health and Human Services, CDC, March 1999.

9. CDC. Recommendations of the US Public Health Service Task Force on the use of zidovudine to reduce perinatal transmission of human immunodeficiency virus. MMWR 1994;43 (no. RR-11).

10. Janssen RS, Holtgrave DR, Valdiserri RO, Shepherd M, Gayle HD, DeCock KM. Serostatus approach to fighting the HIV epidemic: prevention strategies for individuals with HIV infection in the United States. Am J Public Health 2001;91(in press).

\section{The Global HIV and AIDS Epidemic, 2001}

Human immunodeficiency virus (HIV) infection and acquired immunodeficiency syndrome (AIDS) are pandemic and pose one of the greatest challenges to global public health. As a bloodborne and sexually transmitted infection, HIV has variable patterns of transmission and impact among world regions and has disproportionately affected disadvantaged or marginalized persons such as commercial sex workers, injection drug users, men who have sex with men (MSM), and persons living in poverty. HIV infection 
Global HIV and AIDS Epidemic - Continued

has caused approximately 20 million deaths; an estimated 36 million persons are infected (Figure 1). On the basis of data from the Joint United Nations Program on AIDS (UNAIDS) and other sources, this report summarizes epidemiologic trends, highlights several HIV and AIDS prevention milestones, and describes some prevention activities for the coming decade (1-4).

\section{Sub-Saharan Africa (SSA)}

$\mathrm{SSA}^{*}$ is the region of the world most severely affected by HIV and AIDS. Uganda, Kenya, and Tanzania were among the countries where the HIV epidemic was first recognized during the early 1980s. In 2000, an estimated 25.3 million persons in SSA were infected with HIV, and the average national prevalence of HIV infection among persons aged $15-49$ years was $8.8 \%$. Approximately four million new infections occurred during 2000. Approximately $10 \%$ of persons aged 15-49 years are infected in 16 countries, including seven in southern and eastern Africa, where approximately $20 \%$ are infected. In Botswana, the country with the highest prevalence, $36 \%$ of the adult population is infected with HIV (Figure 2).

Despite these trends, intensive and aggressive prevention programs for behavior change, condom promotion, voluntary HIV counseling and testing, and blood transfusion safety have lowered prevalence or slowed HIV transmission in several SSA countries. For example, in Uganda during 1990-2000, overall adult HIV prevalence declined from

*Angola, Benin, Botswana, Burkina Faso, Burundi, Cameroon, Cape Verde, Central African Republic, Chad, Congo, Cotê d'Ivoire, Democratic Republic of Congo, Djibouti, Eritrea, Ethiopia, Equatorial Guinea, Gabon, Gambia, Ghana, Guinea, Guinea-Bissau, Kenya, Lesotho, Liberia, Malawi, Mali, Mauritania, Mozambique, Namibia, Niger, Nigeria, Rwanda, Senegal, Sierra Leone, South Africa, Swaziland, Tanzania, Togo, Sao Tome-Principe, Uganda, Zambia, and Zimbabwe.

FIGURE 1. Number* of adults and children estimated to be infected with HIV and AIDS - worldwide, 2000

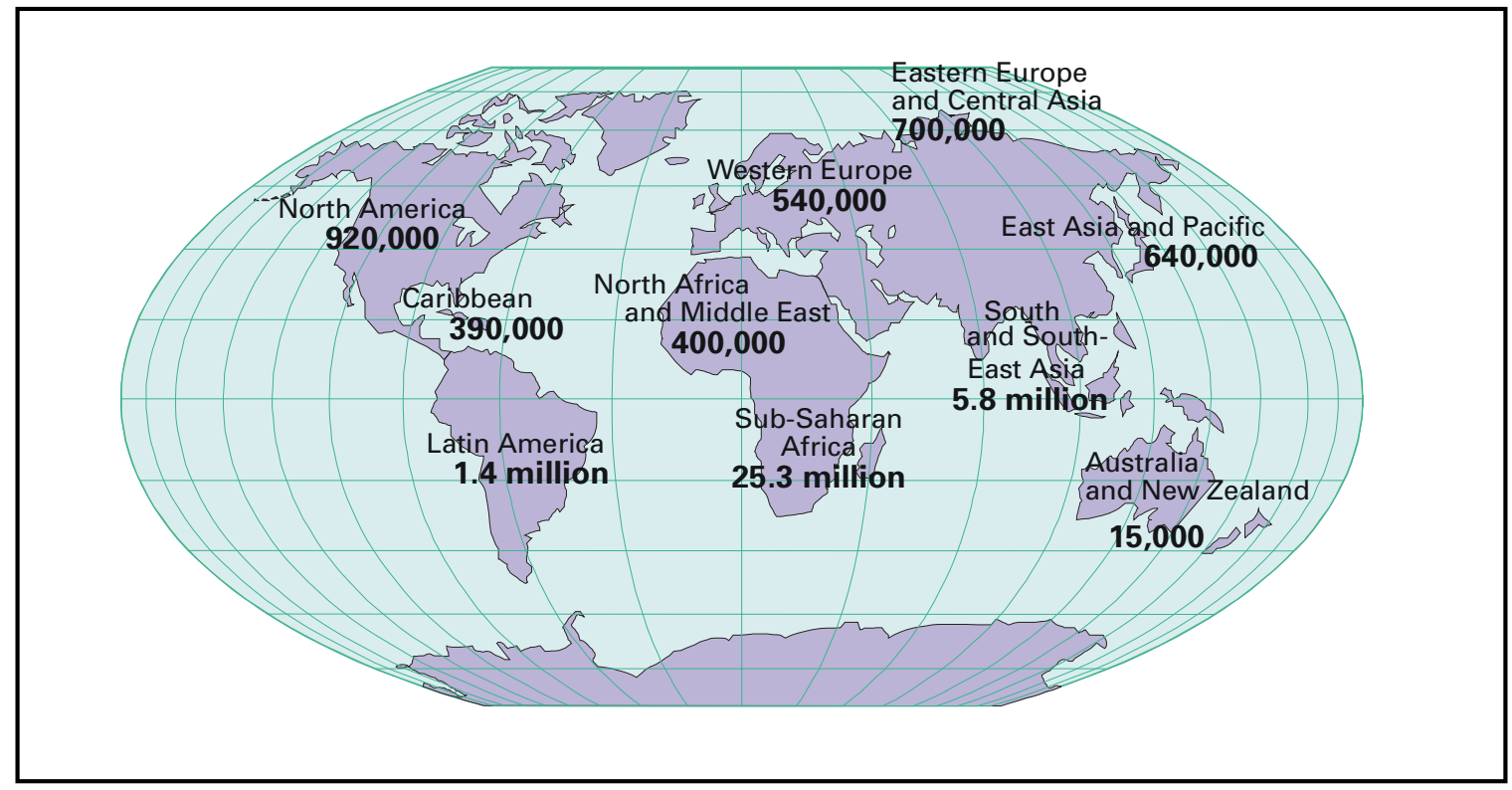

* $\mathrm{n}=36.1$ million.

Source: Jointed United Nations Program on AIDS. 
Global HIV and AIDS Epidemic - Continued

FIGURE 2. Estimated number of new HIV infections, by region and year - worldwide, 1980-1999

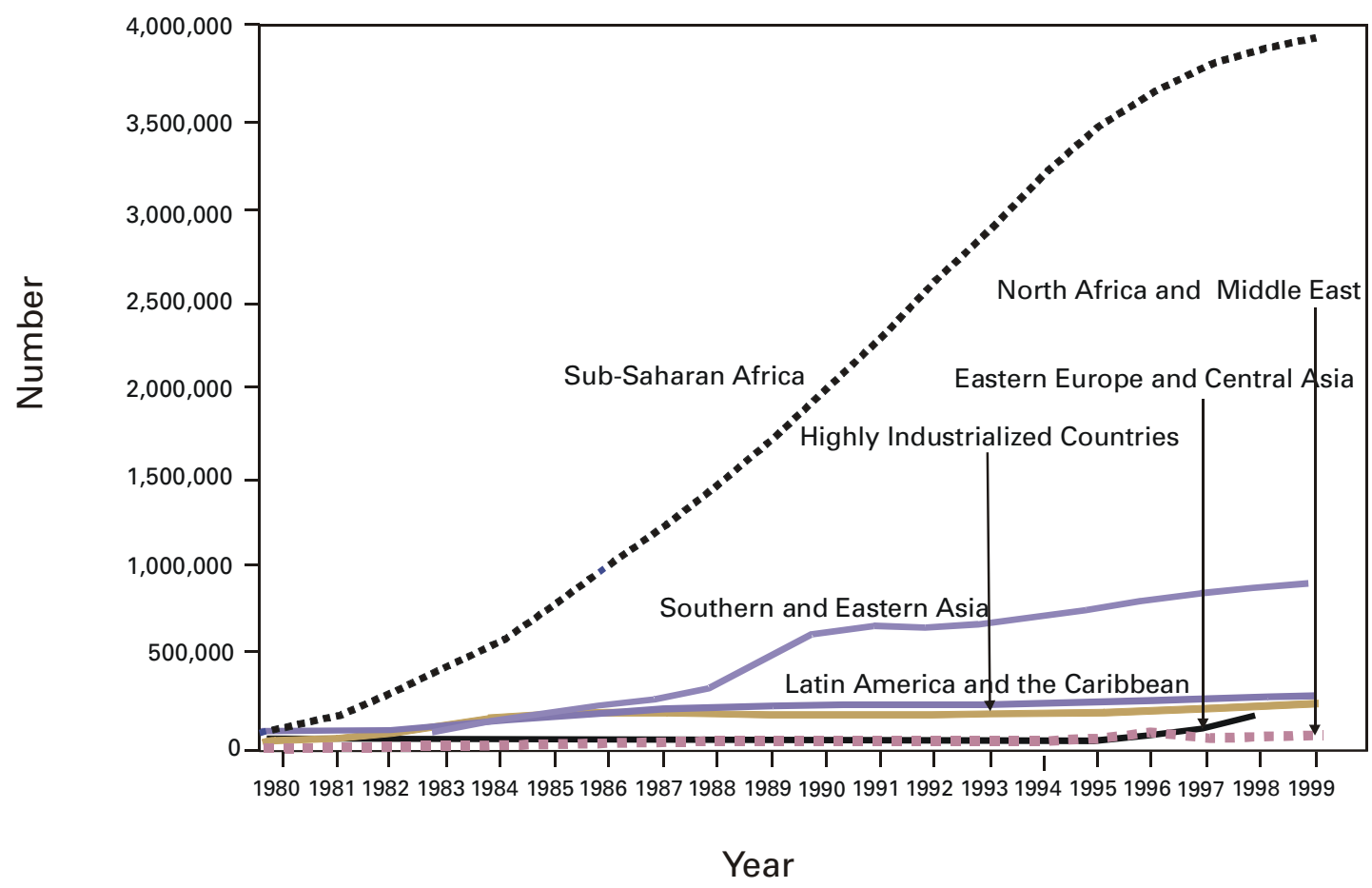

Source: Jointed United Nations Program on AIDS.

14\% to $8 \%$. In Masaka, Uganda, HIV prevalence among females aged 20-24 years decreased from $20.9 \%$ during $1989-1990$ to $13.8 \%$ during 1996-1997 (5). Also, in Lusaka, Zambia, which had an early and severe epidemic, HIV prevalence declined among females aged 15-19 years attending prenatal clinics from $27 \%$ in 1993 to $17 \%$ in 1998 . In West Africa, Senegal has maintained a prevalence of approximately $2 \%$; prevention efforts have included regulating commercial sex, intensive condom promotion, treatment of sexually transmitted diseases (STDs), and community mobilization.

Asia

The epidemic continues to spread in the world's most populous areas, where the infrastructure for an effective response is underdeveloped. In China, HIV prevalence was as high as $82 \%$ among injection drug users and $6 \%$ in commercial sex workers during 1998-1999. A sustained increase also occurred in all reported STDs among males and females during 1989-1998. In India, the estimated HIV infection rate among persons aged $15-49$ years is $0.7 \%$. As of mid-1998, an estimated 3.5 million persons were infected with HIV. An exception to countries with increasing prevalence is Thailand, where the epidemic began in the mid-1980s among injection drug users and commercial sex workers and their clients and spread rapidly to the wider population through heterosexual transmission. In response, health officials developed HIV and AIDS surveillance systems and mounted a sustained and effective response, including the "100\% condom use" campaign for commercial sex. The resulting decline in STD and HIV transmission was reflected in a decrease in STD rates and HIV prevalence in military recruits and women attending prenatal clinics. 
Global HIV and AIDS Epidemic - Continued

\section{Eastern Europe and Central Asia}

Eastern Europe has had recent and rapid growth of HIV infection among injection drug users. By January 1999, approximately 10,000 HIV cases had been reported in the Russian Federation. By December 2000, the cumulative total increased to 70,000 , and HIV infection among injection drug users was reported from 82 of the 89 regions in the Russian Federation. Ukraine was the country most affected in Eastern Europe and Central Asia, where newly reported infections increased from 47 cases per year during $1992-1994$ to approximately 15,000 cases in 1997. Ukraine accounted for $90 \%$ of all AIDS cases reported in the region in 1998 and 1999. HIV probably will spread further in the region as a result of the large number of injection drug users, increasing rates of STDs, the growing commercial sex industry, and socioeconomic transitions.

\section{United States and Western Europe}

In Western Europe and the United States, deaths attributed to HIV have declined substantially since the introduction of highly active antiretroviral therapies. However, reported increases in STDs among MSM and other indicators of increased risk-taking behavior may be leading to an increase in HIV transmission.

\section{Latin America and the Caribbean}

In Latin America and the Caribbean, the leading modes of transmission include sex between men, sex between men and women, and injection drug use. By December 2000, an estimated 1.4 million adults and children were infected with HIV/AIDS in the region compared with 1.3 million in 1999. Barbados, Belize, Dominican Republic, Guyana, Haiti, and Suriname have an HIV prevalence of approximately $1 \%$. The Caribbean, with an adult prevalence of $2.1 \%$, is the second most affected world region. In Brazil, reported HIV-related deaths have declined from approximately 25 per 100,000 in 1995 to approximately 15 per 100,000 in 1999, in large part because of the government policy of providing universal, free access to antiretroviral therapies (6).

Reported by: Global AIDS Program, National Center for HIV, STD, and TB Prevention, CDC.

Editorial Note: HIV and AIDS is the leading cause of death in Africa and the fourth leading cause of death worldwide. In the countries most affected in Africa, life expectancy has declined by 10 years and infant death rates have doubled. In countries with the highest prevalence, such as Botswana, South Africa, and Zimbabwe, the full impact of the epidemic has not been felt because those infected recently have not developed symptoms. Equally important is the effect of HIV deaths on families, social systems, and national growth and development. Young adults who contribute substantially to countries' gross domestic product are most commonly affected. In families, loss of one or both parents to HIV can lead to loss of income, cessation of children's education, increased child labor, and disruption of family and social support systems. For example, in Zambia, a shortage of school teachers has occurred because more teachers are dying of AIDS than can be trained to replace them.

Considerable heterogeneity of rates exist in HIV-infected countries throughout the world, and the differences have been attributed to risk factors associated with the spread of HIV and AIDS. They include migration, economic instability, drug use, STDs, low levels of literacy, and poverty. These are formidable challenges to implementing effective prevention programs (4). Although the earliest epidemiologic studies described the modes of transmission of HIV and AIDS and provided insights into the types of interventions needed to prevent transmission, this understanding has been difficult to translate into 
Global HIV and AIDS Epidemic - Continued

effective interventions worldwide. The HIV epidemic has challenged public health agencies to develop new and often controversial prevention programs that contradict established practices and social norms.

Despite these challenges, even countries with modest resources have demonstrated that the epidemic can be stabilized or reversed. In these countries, successful programs have included strong, high-level political leadership for HIV prevention, a national program plan, adequate funding, and strong community involvement. Effective and feasible interventions for HIV prevention and control are available. Quality testing and guidelines for blood use can promote a safer blood supply. Widespread condom promotion can reduce HIV seroprevalance in high-risk populations, and education programs for young persons can result in decreased risk-taking behavior. Increasing access to drug treatment and providing education about and increasing access to clean syringes can reduce infection risk in drug using populations. Prophylaxis with co-trimoxazole can prevent certain opportunistic infections and reduce the number of HIV-related deaths. Administering antiviral agents, such as niverapine or short-course zidovudine, and advice to women on breastfeeding, can substantially reduce mother-to-infant transmission (7). Improving treatment for STDs can slow HIV infection rates (8). When effective STD treatment programs continue to be compromised by weak infrastructure, important opportunities for HIV prevention are lost. Efforts are needed to strengthen STD services and to integrate these with HIV prevention and control programs.

The social stigma associated with HIV infection in many cultures combined with difficulties in providing treatment or services for infected persons are major barriers to expanding voluntary counseling and testing for HIV. Persons who may benefit from knowing their serostatus often reject counseling and testing because they fear the consequences of disclosure of their HIV status. Other disincentives are the lack of resources for care and treatment and the sense that little is gained from learning that one is infected with HIV. Prevention programs must be accompanied by efforts to improve the care of HIV-infected persons. Isoniazid prophylaxis for TB (9) and other low-cost interventions should be incorporated into prevention programs (10).

The most effective intervention therapy for persons infected with HIV is the use of a combination of antiretroviral agents. However, the high cost of these regimens and the infrastructure needed to monitor their use have put these medications beyond the reach of most HIV-infected persons. Although the price of these drugs has fallen, making treatment a possibility for a greater number of persons, infrastructures to support the effective use of these medications remain inadequate and need strengthening. Given the needs for both prevention and treatment, public health officials and international donors will need to determine the best mix of drug treatment and prevention programs.

Globally, the HIV epidemic has intersected with other, underlying public health problems, most notably tuberculosis (TB). TB remains the principal cause of death in persons with HIV infection worldwide. National TB rates have escalated over the past decade in SSA and South-East Asia. Since the mid-1980s, in many African countries with wellorganized programs, annual TB notification rates have increased fourfold, reaching peaks of more than 400 cases per 100,000 population. In some countries, up to $70 \%$ of patients with sputum smear-positive pulmonary TB are HIV-infected. To the extent possible, integration of HIV and TB prevention programs should be a priority in these countries.

The increase in HIV infection and AIDS deaths has led to increases in aid from governments and national and international organizations and foundations. Since 1999, the U.S. 
Global HIV and AIDS Epidemic - Continued

government increased its financial support to HIV/AIDS prevention and care programs in affected countries. For fiscal year 2001, this totaled \$457.5 million. Participating agencies include the U.S. Agency for International Development, the U.S. Department of Health and Human Services (including CDC, and the Health Resources and Services Administration), the Department of Defense, the Department of Labor, and the Department of Commerce. The National Institutes of Health recently launched the Comprehensive International Program for Research on AIDS (CIPRA) to assist developing countries with research agendas relevant to their populations and to enhance infrastructure. CDC established the Global AIDS Program (GAP) to implement international HIV prevention efforts in collaboration with other federal agencies. The program emphasizes sustaining intervention programs for primary prevention of HIV infection, infrastructure development and laboratory support, and home- and community-based care for persons with HIV infection. CDC is supporting these activities in 24 countries in partnership with other U.S. agencies, national ministries of health, UNAIDS, and other international agencies.

\section{References}

1. Piot $P$, Bartos $M$, Ghys PD, Walker N, Schwartlander B. The global impact of HIV/AIDS. Nature 2001;410:968-73.

2. Joint United Nations Program on HIV/AIDS. Report on the HIV/AIDS global epidemicJune 2000. Geneva, Switzerland: Joint United Nations Program on HIV/AIDS, 2000; UNAIDS/ $00.13 \mathrm{E}$.

3. United Nations Children's Fund. The progress of nations 2000. New York, New York: United Nations Children's Fund, 2000.

4. Gayle HD, Hill GL. Global impact of human immunodeficiency virus and AIDS. Clin Microbiol Rev 2001;14:327-35.

5. Kamali A, Carpenter LM, Whitworth JAG, Pool R, Ruberantwari A, Ojiywa A. Seven year trends in HIV-1 infection rates, and changes in sexual behavior, among adults in rural Uganda. AIDS 2000;14:427-34.

6. Boletim Epidemiologico AIDS Brazil. Anno XIII no. 03-36 a 52 semanos epidemiologicasutobro a dezembro de 2000.

7. Shaffer NR, Chauchoowong PA, Mock C, et al. Short-course zidovudine for perinatal transmission of HIV-1 transmission in Bangkok, Thailand: a randomised controlled trial. Lancet 1999;353:773-80.

8. Grosskurth HF, Mosha J, Todd EM, et al. Impact of improved treatment of sexually transmitted diseases on HIV infection in rural Tanzania: randomised controlled trial. Lancet 1995;346:530-6.

9. Pape J, Jean S, Ho J, Hafner A, Jr Johnson WD. Effect of isoniazid prophylaxis on incidence of active tuberculosis and progress of HIV infection. Lancet 1993;342:268-72.

10. Wiktor SZ, Sassan-Morokoro M, Grant A, Abouya L, et al. Efficacy of trimethoprimsulphamethoxazole prophylaxis to decrease morbidity and mortality in HIV-1 infected persons with tuberculosis in Abijan, Cote D'lvoire: a randomized controlled trail. Lancet 1999;353:1469-75. 


\section{HIV Incidence Among Young Men Who Have Sex With Men - Seven U.S. Cities, 1994-2000}

Twenty years after the first report on human immunodeficiency virus (HIV) infection in the United States, studies of sexually transmitted diseases (STDs) and sexual behaviors suggest a resurgent HIV epidemic among men who have sex with men (MSM) (1,2). However, few recent studies have measured HIV incidence in this population (3-7). To determine HIV incidence among young MSM, CDC analyzed data from the Young Men's Survey (YMS), a study that found a high prevalence of HIV and associated risks among MSM aged 15-22 years sampled in seven U.S. cities (8). This report confirms high HIV incidence among these young men.

YMS Phase I was a cross-sectional, multisite, venue-based sample survey of men aged 15-22 years who attended public venues where young MSM congregate (e.g., urban shopping blocks, dance clubs, bars, and young gay organizations) (8). During the survey start-up in each city, formative research was conducted to identify all venues frequented by young MSM, and the days and times when young men frequented these venues. A three-stage sampling plan was used to randomly select venues from the sampling frame of venues and then to randomly select times. Sampled venues and times were then scheduled for the third stage of sampling in which young men were sampled at 194 venues in Baltimore, Maryland; Dallas, Texas; Los Angeles, California; Miami, Florida; New York, New York; San Francisco, California; and Seattle, Washington. Eligible men (i.e., local residents aged 15-22 years) were recruited for the survey. Participants were asked about their risk behaviors and demographics, and counseled about and tested for HIV; blood specimens were tested anonymously for HIV. Participants were scheduled to return in 2 weeks for test results, posttest counseling, and service referrals. Duplicate enrollees were removed from the database by various screening methods, including the Miragen Assay, which profiles antibodies. Because no association was found between frequency of venue attendance and HIV prevalence, the data were not weighted according to venue attendance.

An enzyme immunoassay was used to screen blood specimens for HIV antibody. Repeatedly reactive specimens were confirmed by Western blot or indirect immunofluorescence. To estimate HIV incidence, a serologic testing algorithm was used to determine recent HIV seroconversion (STARHS) (9). HIV-positive specimens were tested with a sensitive HIV-1 whole viral lysate EIA (3A11) (Abbott, Abbott Park, Illinois) that detects infection approximately 30 days after transmission. Specimens that were 3A11reactive were retested using the 3A11-LS (less-sensitive), which detects HIV infection approximately 140 days after the $3 A 11$ (95\% confidence interval [Cl]=125-156 days). A specimen that was 3A11-reactive but 3A11-LS-nonreactive was categorized as a recent infection. Incidence was calculated using the number of persons with recent infections as the numerator and the number of persons with recent infections plus the number of persons who were HIV-negative as the denominator. Incidence estimates were adjusted for HIV-positive specimens that were not tested by STARHS. Incidence was annualized to units of percent per year. All data were analyzed using SAS version 6.12.

In the seven cities, 3492 young MSM enrolled (range for the seven cities: 357-702 MSM) (8). The enrollment rate was $62 \%$ (range: $51 \%-75 \%$ ). The prevalence of HIV infection was $7.2 \%$ (range: $2.2 \%-12.1 \%$ ), increased with age, and was higher among blacks, Hispanics, and men of mixed race than among whites or Asians/Pacific Islanders (Figure 1). These findings and the high prevalence of unprotected anal sex during the 
FIGURE 1. HIV prevalence among men aged 15-22 years who have sex with men, by race/ethnicity and age group — seven U.S. cities, ${ }^{*}$ 1994-1998

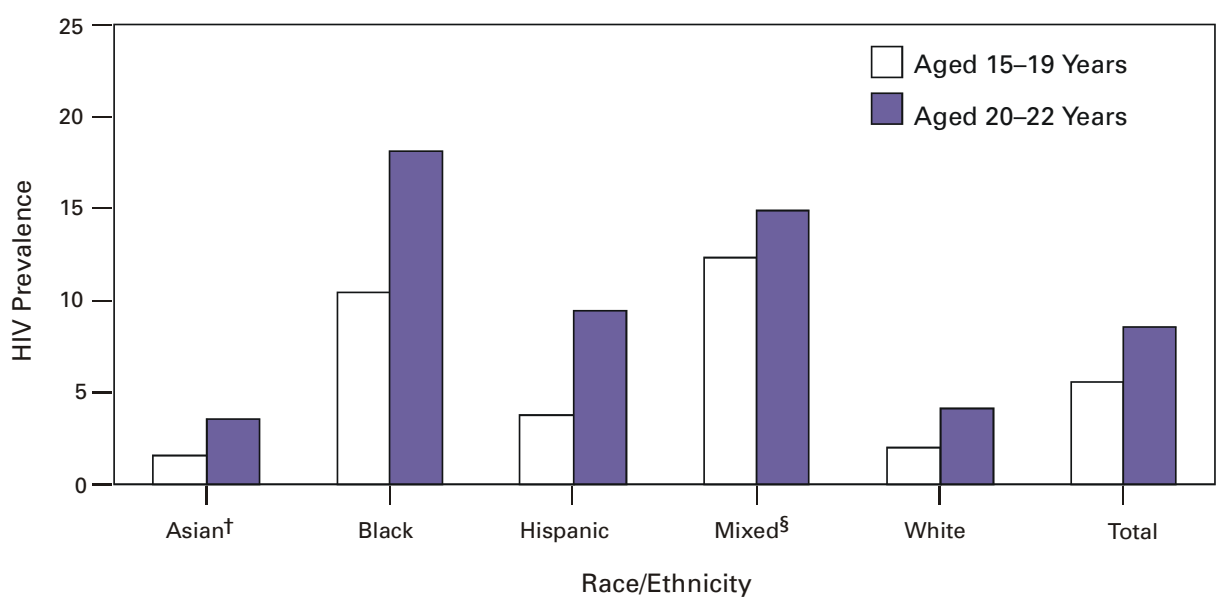

*Baltimore, Maryland; Dallas, Texas; Los Angeles, California; Miami, Florida; New York City, New York; San Francisco, California; and Seattle, Washington.

${ }^{\dagger}$ Asian indicates Asian/Pacific Islander.

${ }^{\S}$ From multiple racial backgrounds.

preceding 6 months (41\%; range: 33\%-49\%) suggested that HIV incidence was high among these young men.

Of the 3449 young MSM tested, 249 were HIV-positive. Of the 249 HIV-positive specimens, 224 were tested by STARHS; 29 met the criteria for recent infection (Table 1). HIV incidence was $2.6 \%$ overall, $3.5 \%$ among persons aged $20-22$ years, $4.0 \%$ among blacks, and $5.4 \%$ among men of mixed race. Of the 29 persons with recent infections, 14 were from New York City. HIV incidence was similar among homosexual and bisexual men. Recent risk behaviors associated with high HIV incidence were having $\geq 5$ male sex partners during the preceding 6 months, having unprotected anal sex with men, or having injected drugs.

During 1998-2000, YMS Phase II was conducted to sample MSM aged 23-29 years in six of the seven cities (excluding San Francisco). Data are preliminary. Of the 2942 young MSM, 1409 (48\%) were white, 651 (22\%) were Hispanic, and 497 (17\%) were black. Of these, 373 (13\%) were HIV-positive; HIV prevalence was $7 \%$ among whites, $14 \%$ among Hispanics, and $32 \%$ among blacks. Of the 373 HIV-positive specimens, 290 were STARHStested; 38 were recent infections. Overall incidence was $4.4 \%(95 \% \mathrm{Cl}=2.9 \%-6.7 \%)$; HIV incidence was $2.5 \%$ among whites $(95 \% \mathrm{Cl}=1.4 \%-4.6 \%)$, 3.5\% among Hispanics $(95 \%$ $\mathrm{Cl}=1.4 \%-8.6 \%$ ), and $14.7 \%$ among blacks (95\% $\mathrm{Cl}=7.9 \%-27.1 \%)$.

Reported by: W McFarland, MD, MH Katz, MD, San Francisco Dept of Public Health, San Francisco; SR Stoyanoff, MPH, Los Angeles County Dept of Health Svcs, Los Angeles, California. DA Shehan, Univ of Texas Southwestern Medical Center at Dallas, Dallas, Texas. M LaLota, MPH, Florida Dept of Health. DD Celentano, ScD, Johns Hopkins Univ School of Hygiene and Public Health, Baltimore, Maryland. BA Koblin, PhD, New York Blood Center, LV Torian, PhD, New York City Dept of Health, New York, New York. H Thiede, DVM, Public Health-Seattle and King County, Seattle, Washington. Clinical Biochemistry Br, Div of Environmental Health Laboratory Sciences, National Center for Environmental Health; Prevention Svcs Research Br, Statistics and Data Management Br, Office of the Director, Div of HIV/AIDS PreventionSurveillance and Epidemiology, National Center for HIV, STD, and TB Prevention, CDC. 
HIV Among Young Men Who Have Sex With Men - Continued

TABLE 1. HIV prevalence* and incidence ${ }^{\dagger}$ among men aged 15-22 years who have sex with men - seven cities ${ }^{\S}$, United States, 1994-1998

\begin{tabular}{|c|c|c|c|c|c|}
\hline Characteristic & No. ${ }^{\pi}$ & $\begin{array}{c}\text { HIV } \\
\text { prevalence } \\
(\%)\end{array}$ & $\begin{array}{l}\text { No. with } \\
\text { recent HIV } \\
\text { infection }\end{array}$ & $\begin{array}{c}\text { HIV } \\
\text { incidence } \\
\text { (\% per year) }\end{array}$ & $\left(95 \% \mathrm{Cl}^{* *}\right)$ \\
\hline \multicolumn{6}{|l|}{ Age group (yrs) } \\
\hline $15-19$ & 1542 & ( 5.6$)$ & 8 & 1.6 & $(0.5-3.7)$ \\
\hline $20-22$ & 1906 & ( 8.6) & 21 & 3.5 & $(1.8-6.3)$ \\
\hline \multicolumn{6}{|l|}{ Race/Ethnicity } \\
\hline \multicolumn{6}{|l|}{ American Indian/ } \\
\hline Alaska Native & 45 & (6.7) & 0 & 0.0 & $(0.0-34.7)$ \\
\hline Asian/Pacific Islander & 203 & $(3.0)$ & 0 & 0.0 & $(0.0-6.6)$ \\
\hline Black & 587 & (14.1) & 7 & 4.0 & $(1.3-9.9)$ \\
\hline Hispanic & 1027 & (6.9) & 6 & 1.8 & $(0.5-4.8)$ \\
\hline Mixed & 335 & (13.4) & 6 & 5.4 & $(1.5-14.8)$ \\
\hline White & 1246 & ( 3.3$)$ & 10 & 2.4 & $(1.0-5.3)$ \\
\hline \multicolumn{6}{|l|}{ City } \\
\hline Baltimore & 352 & ( 8.5$)$ & 1 & 0.8 & $(0.0-6.0)$ \\
\hline Dallas & 523 & (6.5) & 5 & 3.3 & $(0.9-8.9)$ \\
\hline Los Angeles & 506 & (8.3) & 4 & 2.9 & $(0.7-8.4)$ \\
\hline Miami & 484 & ( 5.8$)$ & 1 & 0.7 & $(0.0-4.5)$ \\
\hline New York & 530 & $(12.1)$ & 14 & 7.6 & (3.3-15.8) \\
\hline San Francisco & 690 & $(6.2)$ & 3 & 1.2 & $(0.2-4.5)$ \\
\hline Seattle & 364 & $(2.2)$ & 1 & 0.7 & $(0.0-5.3)$ \\
\hline \multicolumn{6}{|l|}{ Sexual identity ${ }^{\dagger \dagger}$} \\
\hline Homosexual & 2240 & ( 7.5) & 19 & 2.6 & $(1.3-4.8)$ \\
\hline Bisexual & 1025 & (6.5) & 7 & 2.2 & $(0.7-5.4)$ \\
\hline Heterosexual & 132 & (3.8) & 2 & 4.0 & $(0.3-19.1)$ \\
\hline Transgender & 42 & $(14.3)$ & 1 & 7.1 & $(0.1-52.9)$ \\
\hline \multicolumn{6}{|l|}{$\begin{array}{l}\text { Sex partners during } \\
\text { preceding } 6 \text { months }\end{array}$} \\
\hline Men & 2522 & ( 7.8) & 19 & 2.4 & $(1.2-4.3)$ \\
\hline Men and women & 589 & (6.6) & 8 & 4.3 & $(1.5-10.1)$ \\
\hline Women & 111 & ( 1.8$)$ & 0 & 0.0 & $(0.0-9.8)$ \\
\hline None & 227 & ( 5.3$)$ & 2 & 2.4 & $(0.2-11.3)$ \\
\hline \multicolumn{6}{|l|}{$\begin{array}{l}\text { No. male partners during } \\
\text { preceding } 6 \text { months }\end{array}$} \\
\hline$\geq 5$ & 791 & (9.7) & 10 & 4.0 & $(1.5-8.8)$ \\
\hline $1-4$ & 2320 & (6.8) & 17 & 2.3 & $(1.1-4.3)$ \\
\hline None & 338 & (4.1) & 2 & 1.6 & $(0.1-7.5)$ \\
\hline \multicolumn{6}{|c|}{$\begin{array}{l}\text { Reported risk behaviors } \\
\text { during preceding } 6 \text { months }\end{array}$} \\
\hline $\begin{array}{l}\text { Unprotected anal } \\
\text { sex with men }\end{array}$ & 1408 & $(8.5)$ & 17 & 3.8 & $(1.8-7.2)$ \\
\hline \multicolumn{6}{|l|}{ Sex while "high" } \\
\hline on alcohol/drugs & 1756 & $(7.6)$ & 17 & 3.0 & $(1.4-5.7)$ \\
\hline Injected drugs & 120 & $(19.2)$ & 2 & 6.0 & $(0.5-26.4)$ \\
\hline Total & 3449 & ( 7.2) & 29 & 2.6 & $(1.5-4.4)$ \\
\hline
\end{tabular}

* Enzyme immunoassay could not be conducted on 43 blood specimens because of insufficient volumes.

${ }^{\dagger}$ Of the 249 HIV-positive specimens, 224 had quantity sufficient for a serologic testing algorithm for determining recent HIV seroconversion.

${ }^{\S}$ Baltimore, Maryland; Dallas, Texas; Los Angeles, California; Miami, Florida; New York, New York; San Francisco, California; and Seattle, Washington.

"Numbers may not add to total because, for some characteristics, a possible response category was "don't know" or "refuse." For "reported risk behaviors," only the subsamples with these risk behaviors are shown.

** Confidence interval.

tt Participants were asked whether they considered their sexual identity to be straight (heterosexual), bisexual/gay (homosexual), or transgender. 
HIV Among Young Men Who Have Sex With Men - Continued

Editorial Note: The findings in this report document a high incidence of HIV among a sample of young MSM, particularly blacks in their 20s. The overall incidence was comparable to that reported in recent studies of adult MSM (3-7). In the 20th year of the HIV epidemic, young MSM in these cities continue to be at high risk for HIV infection.

This is the first published report using STARHS to provide incidence estimates in community-recruited sample surveys. In this study, HIV incidence was high among MSM in their 20s and young racial/ethnic minority MSM, especially blacks. Because there were no earlier incidence studies of MSM aged 15-22 years, it is unknown whether HIV transmission among very young MSM is increasing. However, the preliminary high incidence data among MSM aged 23-29 years in YMS Phase II, in conjunction with other recent findings on STDs and sexual behaviors $(1,2)$, are of concern and may suggest a resurgent MSM epidemic among young MSM in the late 1990s.

The findings in this report are subject to at least three limitations. First, although enrollment rates were high, sampling was conducted through outreach at venues, and it is not known whether young men with recent high-risk behaviors were more likely to enroll. Second, young men were sampled only at randomly selected venues, and incidence may have been lower if young MSM who did not go to venues or did not live in cities had been sampled. Third, data for YMS Phase II are preliminary, particularly because not all specimens were STARHS-tested and the final results may change slightly.

Young MSM need to be targeted with early and sustained prevention efforts specifically tailored to their needs. In a recent health bulletin sent to HIV prevention providers, CDC encouraged local areas to assess their current situation and services and, if necessary, develop new prevention messages, improve the quality of STD clinical services for MSM, expand prevention and outreach for HIV-positive MSM, and address the factors that may be contributing to high incidence such as the impact of racism and homophobia on risk behavior ( 10$)$. The high HIV incidence described in this report calls for a vigorous public health and community response to prevent HIV.

References

1. Wolitski RJ, Valdiserri RO, Denning PH, Levine WC. Are we headed for a resurgence in the HIV epidemic among men who have sex with men? Am J Public Health 2001;91:883-8.

2. CDC. Resurgent bacterial sexually transmitted diseases among men who have sex with men-King County, Washington, 1997-1999. MMWR 1999;48:773-7.

3. Buchbinder SP, Douglas JM, McKirnan DJ, et al. Feasibility of human immunodeficiency virus vaccine trials in homosexual men in the United States. J Infect Dis 1996;174:954-61.

4. Koblin BA, Taylor PE, Avrett S, Stevens CE. The feasibility of HIV-1 vaccine trials among gay/bisexual men in New York City. AIDS 1996;10:1555-61.

5. McFarland W, Busch MP, Kellogg TA, et al. Detection of early HIV infection and estimation of incidence using a sensitive/less-sensitive enzyme immunoassay testing strategy at anonymous counseling and testing sites in San Francisco. J Acquir Immune Defic Syndr 1999;22:484-9.

6. Osmond $\mathrm{DH}$, Page K, Wiley J, et al. HIV infection in homosexual and bisexual men 18 to 29 years of age. Am J Public Health 1994;84:1933-7.

7. Weinstock H, Sweeney S, Satten GA, et al. HIV seroincidence and risk factors among patients repeatedly tested for HIV attending sexually transmitted disease clinics in the United States, 1991 to 1996. J Acquir Immune Defic Syndr 1998;19:506-12.

8. Valleroy LA, MacKellar DA, Karon JM, et al. HIV prevalence and associated risks in young men who have sex with men. JAMA 2000;284:198-204.

9. Janssen RS, Satten GA, Stramer SL, et al. New testing strategy to detect early HIV-1 infection for use in incidence estimates and for clinical and prevention purposes. JAMA 1998;280:42-8. 
HIV Among Young Men Who Have Sex With Men - Continued

10. CDC. Taking action to combat increases in STDs and HIV risk among men who have sex with men. Atlanta, Georgia: US Department of Health and Human Services, CDC, May 2001.

Notice to Readers

\section{The 20th Year of AIDS: A Time to Re-Energize Prevention}

Since the first acquired immunodeficiency syndrome (AIDS) cases were reported in 1981, human immunodeficiency virus (HIV) has caused approximately 22 million deaths worldwide. In the United States, approximately 400,000 persons have died, and approximately one million have been infected. However, numerous persons have avoided infection through prevention efforts, and many lives have been prolonged through advances in treatment.

The 20th year of AIDS is a milestone in the fight against HIV/AIDS; it is a time to remember persons who have become ill and died from the disease and to reflect on the progress made in both HIV prevention and treatment. A way to commemorate those persons who have died from AIDS is to accelerate efforts to stop HIV transmission. Accordingly, at this milestone, CDC has outlined a new strategy to reduce further HIV infection.

The response to HIV/AIDS in the United States has demonstrated the necessity of collaboration between health officials and affected communities. Since the mid-to-late 1980s, CDC has worked with all sectors of society (e.g., state and local public health, media, business, religious, medical, and academic and community-based organizations) to inform the public about AIDS and implement prevention efforts. These efforts evolved from public information campaigns to highly targeted community-based programs using proven behavior interventions. During this time, U.S. infection rates declined dramatically.

New strategies are needed to maintain and accelerate progress in HIV/AIDS prevention that sustain and reinvigorate communities most severely affected during the early years of the epidemic, particularly men who have sex with men and to meet the evolving needs of an increasingly diverse epidemic. Efforts also must be tailored to equip racial/ ethnic minority communities with the skills and knowledge to prevent HIV infection.

Highly active antiretroviral therapies have improved the length and quality of life for HIV-infected persons. However, some infected persons on treatment assume that they are not infectious and engage in behavior that increases risk for transmission (1). In addition, some persons may have decreased concern about infection because of advances in treatment. Increases in risk behaviors and rates of sexually transmitted diseases among men who have sex with men have been reported from multiple cities, which may herald an increase in HIV transmission.

CDC begins the third decade of HIV/AIDS with a new strategic plan designed to reduce annual infections by half within 5 years. This three-part plan includes: 1 ) intensifying efforts to help all infected persons learn their HIV status; 2) establishing new prevention programs to help HIV-infected persons establish and maintain safer behaviors, combined with improved linkages to treatment and care; and 3) expanding highly targeted prevention programs to reach all HIV-negative persons at greatest risk. 
Notice to Readers - Continued

Additional information about the HIV strategic plan is available at http://www.cdc.gov/ nchstp/od/news/prevention.pdf

HIV prevention programs contribute to healthier behaviors and reduce the number of new HIV infections in the United States. An expanded and sustained commitment to prevention on a global, national, community, and personal level is required to further reduce the number of new infections and of persons living with HIV.

Reference

1. Dukers NHTM, Goudsmit J, de Wit JBF, Prins M, Weverling G-J, Coutinho RA. Sexual risk behaviour relates to the virological and immunological improvements during highly active antiretroviral therapy in HIV-1 infection. AIDS 2001;15:369-78. 
FIGURE I. Selected notifiable disease reports, United States, comparison of provisional 4-week totals ending May 26, 2001, with historical data

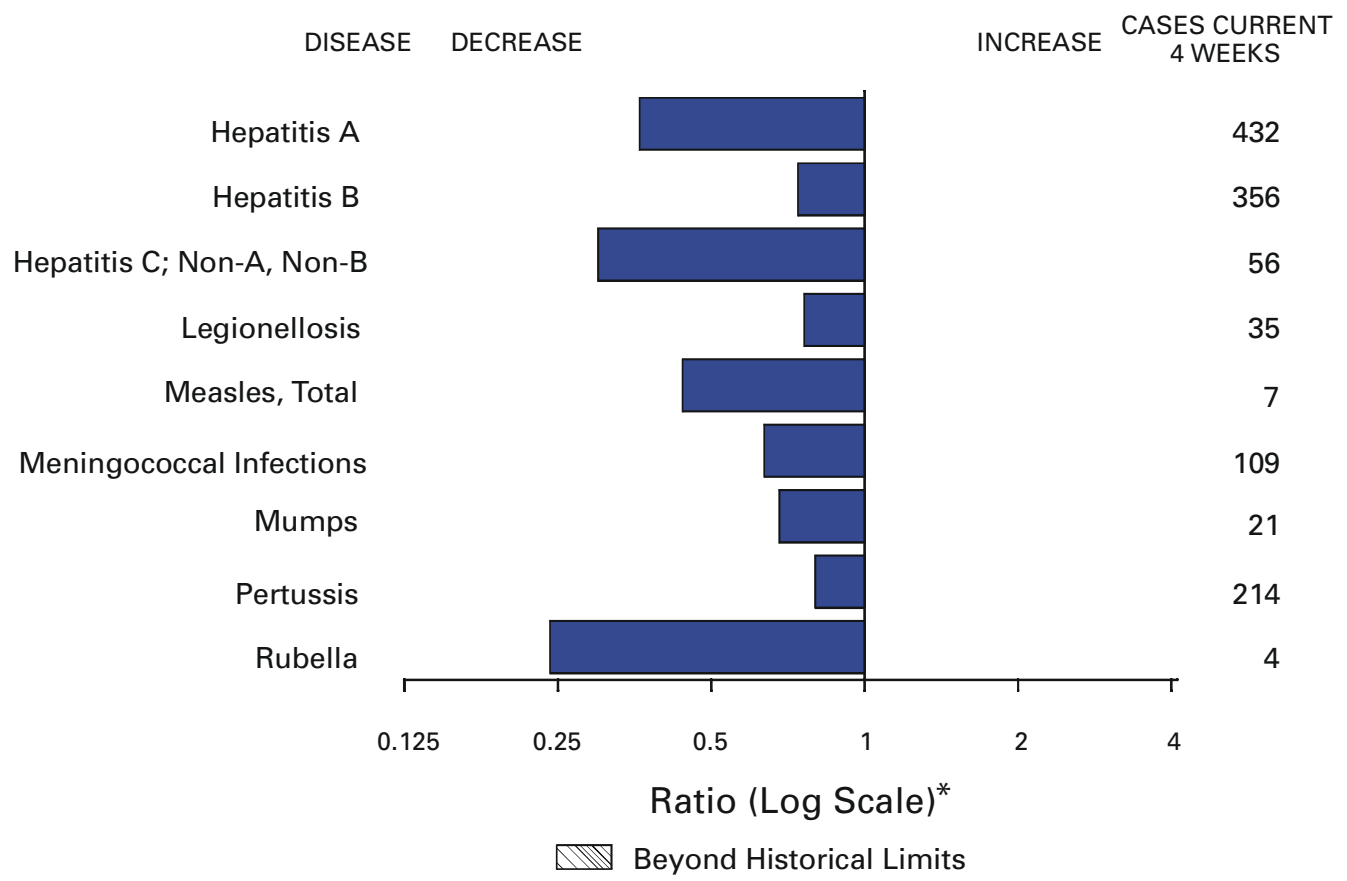

${ }^{*}$ Ratio of current 4-week total to mean of 15 4-week totals (from previous, comparable, and subsequent 4 -week periods for the past 5 years). The point where the hatched area begins is based on the mean and two standard deviations of these 4-week totals.

TABLE I. Summary of provisional cases of selected notifiable diseases, United States, cumulative, week ending May 26, 2001 (21st Week)

\begin{tabular}{|c|c|c|c|c|}
\hline \multirow{7}{*}{$\begin{array}{l}\text { Anthrax } \\
\text { Brucellosis* } \\
\text { Cholera } \\
\text { Cyclosporiasis } \\
\text { Diphtheria } \\
\text { Ehrlichiosis: }\end{array}$} & & Cum. 2001 & \multirow{8}{*}{$\begin{array}{l}\text { Poliomyelitis, paralytic } \\
\text { Psittacosis* } \\
\text { Q fever* } \\
\text { Rabies, human } \\
\text { Rocky Mountain spotted fever (RMSF) } \\
\text { Rubella, congenital syndrome } \\
\text { Streptococcal disease, invasive, group A }\end{array}$} & \multirow{2}{*}{$\frac{\text { Cum. } 2001}{-}$} \\
\hline & & - & & \\
\hline & & 20 & & 4 \\
\hline & & - & & 6 \\
\hline & & 39 & & - \\
\hline & & 1 & & 68 \\
\hline & human granulocytic (HGE)* & 29 & & - \\
\hline & human monocytic (HME)* & 6 & & 1,587 \\
\hline Encephalitis: & California serogroup viral* & - & Streptococcal toxic-shock syndrome* & 23 \\
\hline & eastern equine ${ }^{*}$ & - & Syphilis, congenital ${ }^{\pi}$ & 40 \\
\hline & St. Louis* & - & Tetanus & 6 \\
\hline & western equine* & - & Toxic-shock syndrome & 57 \\
\hline Hansen disea & e (leprosy)* & 22 & Trichinosis & 5 \\
\hline Hantavirus pu & Imonary syndrome ${ }^{*+}$ & 3 & Tularemia* & 13 \\
\hline $\begin{array}{l}\text { Hemolytic ure } \\
\text { HIV infection, }\end{array}$ & $\begin{array}{l}\text { mic syndrome, postdiarrheal* } \\
\text { pediatric }{ }^{* \$}\end{array}$ & $\begin{array}{l}29 \\
72\end{array}$ & $\begin{array}{l}\text { Typhoid fever } \\
\text { Yellow fever }\end{array}$ & $\begin{array}{r}86 \\
-\end{array}$ \\
\hline Plague & & - & & \\
\hline
\end{tabular}

-: No reported cases.

*Not notifiable in all states.

+ Updated monthly from reports to the Division of HIV/AIDS Prevention — Surveillance and Epidemiology, National Center for HIV

STD, and TB Prevention (NCHSTP). Last update April 24, 2001.

§Updated from reports to the Division of STD Prevention, NCHSTP. 
TABLE II. Provisional cases of selected notifiable diseases, United States, weeks ending May 26, 2001, and May 27, 2000 (21st Week)

\begin{tabular}{|c|c|c|c|c|c|c|c|c|c|c|}
\hline \multirow[b]{3}{*}{ Reporting Area } & \multirow{2}{*}{\multicolumn{2}{|c|}{ AIDS }} & \multirow{2}{*}{\multicolumn{2}{|c|}{ Chlamydia $^{\dagger}$}} & \multirow{2}{*}{\multicolumn{2}{|c|}{ Cryptosporidiosis }} & \multicolumn{4}{|c|}{ Escherichia coli 0157:H7* } \\
\hline & & & & & & & \multicolumn{2}{|c|}{ NETSS } & \multicolumn{2}{|c|}{ PHLIS } \\
\hline & $\begin{array}{l}\text { Cum. } \\
2001^{\mathrm{s}} \\
\end{array}$ & $\begin{array}{c}\text { Cum. } \\
2000 \\
\end{array}$ & $\begin{array}{c}\text { Cum. } \\
2001 \\
\end{array}$ & $\begin{array}{l}\text { Cum. } \\
2000 \\
\end{array}$ & $\begin{array}{l}\text { Cum. } \\
2001 \\
\end{array}$ & $\begin{array}{l}\text { Cum. } \\
2000\end{array}$ & $\begin{array}{l}\text { Cum. } \\
2001\end{array}$ & $\begin{array}{l}\text { Cum. } \\
2000 \\
\end{array}$ & $\begin{array}{l}\text { Cum. } \\
2001 \\
\end{array}$ & $\begin{array}{l}\text { Cum. } \\
2000 \\
\end{array}$ \\
\hline UNITED STATES & 11,921 & 14,542 & 248,136 & 280,555 & 558 & 591 & 453 & 661 & 317 & 543 \\
\hline $\begin{array}{l}\text { NEW ENGLAND } \\
\text { Maine } \\
\text { N.H. } \\
\text { Vt. } \\
\text { Mass. } \\
\text { R.I. } \\
\text { Conn. }\end{array}$ & $\begin{array}{r}469 \\
14 \\
13 \\
10 \\
271 \\
40 \\
121\end{array}$ & $\begin{array}{r}975 \\
14 \\
13 \\
1 \\
668 \\
33 \\
246\end{array}$ & $\begin{array}{r}8,920 \\
484 \\
484 \\
226 \\
3,909 \\
1,078 \\
2,739\end{array}$ & $\begin{array}{r}9,358 \\
543 \\
419 \\
221 \\
4,007 \\
1,038 \\
3,130\end{array}$ & $\begin{array}{r}21 \\
3 \\
- \\
9 \\
4 \\
3 \\
2\end{array}$ & $\begin{array}{r}34 \\
5 \\
2 \\
10 \\
10 \\
2 \\
5\end{array}$ & $\begin{array}{r}56 \\
6 \\
10 \\
2 \\
22 \\
4 \\
12\end{array}$ & $\begin{array}{r}76 \\
5 \\
4 \\
2 \\
35 \\
3 \\
27\end{array}$ & $\begin{array}{r}39 \\
6 \\
6 \\
1 \\
16 \\
2 \\
8\end{array}$ & $\begin{array}{r}75 \\
6 \\
6 \\
3 \\
29 \\
5 \\
26\end{array}$ \\
\hline $\begin{array}{l}\text { MID. ATLANTIC } \\
\text { Upstate N.Y. } \\
\text { N.Y. City } \\
\text { N.J. } \\
\text { Pa. }\end{array}$ & $\begin{array}{r}2,254 \\
97 \\
1,028 \\
635 \\
494\end{array}$ & $\begin{array}{r}3,254 \\
157 \\
1,931 \\
722 \\
444\end{array}$ & $\begin{array}{r}25,281 \\
4,607 \\
10,071 \\
2,933 \\
7,670\end{array}$ & $\begin{array}{r}30,992 \\
5,316 \\
11,168 \\
5,036 \\
9,472\end{array}$ & $\begin{array}{r}60 \\
32 \\
25 \\
2 \\
1\end{array}$ & $\begin{array}{r}115 \\
29 \\
76 \\
4 \\
6\end{array}$ & $\begin{array}{r}43 \\
35 \\
1 \\
7 \\
N\end{array}$ & $\begin{array}{r}97 \\
71 \\
7 \\
19 \\
\mathrm{~N}\end{array}$ & $\begin{array}{r}31 \\
20 \\
1 \\
10 \\
-\end{array}$ & $\begin{array}{r}75 \\
38 \\
3 \\
17 \\
17\end{array}$ \\
\hline $\begin{array}{l}\text { E.N. CENTRAL } \\
\text { Ohio } \\
\text { Ind. } \\
\text { Ill. } \\
\text { Mich. } \\
\text { Wis. }\end{array}$ & $\begin{array}{r}926 \\
167 \\
85 \\
433 \\
189 \\
52\end{array}$ & $\begin{array}{r}1,563 \\
174 \\
146 \\
1,003 \\
185 \\
55\end{array}$ & $\begin{array}{r}34,917 \\
4,145 \\
5,849 \\
9,579 \\
11,748 \\
3,596\end{array}$ & $\begin{array}{r}47,772 \\
12,358 \\
5,167 \\
13,863 \\
9,621 \\
6,763\end{array}$ & $\begin{array}{r}181 \\
45 \\
25 \\
1 \\
46 \\
64\end{array}$ & $\begin{array}{r}122 \\
20 \\
8 \\
17 \\
16 \\
61\end{array}$ & $\begin{array}{r}100 \\
32 \\
21 \\
13 \\
18 \\
16\end{array}$ & $\begin{array}{r}122 \\
23 \\
12 \\
38 \\
20 \\
29\end{array}$ & $\begin{array}{r}51 \\
23 \\
9 \\
7 \\
12 \\
12\end{array}$ & $\begin{array}{r}80 \\
14 \\
13 \\
28 \\
17 \\
8\end{array}$ \\
\hline $\begin{array}{l}\text { W.N. CENTRAL } \\
\text { Minn. } \\
\text { lowa } \\
\text { Mo. } \\
\text { N.Dak. } \\
\text { S. Dak. } \\
\text { Nebr. } \\
\text { Kans. }\end{array}$ & $\begin{array}{r}243 \\
47 \\
24 \\
117 \\
1 \\
1 \\
16 \\
38\end{array}$ & $\begin{array}{r}309 \\
47 \\
24 \\
149 \\
- \\
3 \\
19 \\
67\end{array}$ & $\begin{array}{r}12,695 \\
2,497 \\
1,490 \\
4,281 \\
352 \\
754 \\
910 \\
2,411\end{array}$ & $\begin{array}{r}15,523 \\
3,239 \\
2,054 \\
5,163 \\
362 \\
710 \\
1,506 \\
2,489\end{array}$ & $\begin{array}{r}27 \\
- \\
15 \\
6 \\
- \\
3 \\
3 \\
-\end{array}$ & $\begin{array}{r}39 \\
10 \\
11 \\
6 \\
2 \\
3 \\
4 \\
3\end{array}$ & $\begin{array}{r}49 \\
16 \\
7 \\
10 \\
- \\
4 \\
4 \\
8\end{array}$ & $\begin{array}{r}93 \\
23 \\
14 \\
28 \\
5 \\
2 \\
14 \\
7\end{array}$ & $\begin{array}{r}50 \\
21 \\
6 \\
12 \\
3 \\
4 \\
- \\
4\end{array}$ & $\begin{array}{r}84 \\
32 \\
8 \\
21 \\
6 \\
3 \\
10 \\
4\end{array}$ \\
\hline $\begin{array}{l}\text { S. ATLANTIC } \\
\text { Del. } \\
\text { Md. } \\
\text { D.C. } \\
\text { Va. } \\
\text { W.Va. } \\
\text { N.C. } \\
\text { S.C. } \\
\text { Ga. } \\
\text { Fla. }\end{array}$ & $\begin{array}{r}3,720 \\
72 \\
436 \\
297 \\
270 \\
28 \\
190 \\
250 \\
392 \\
1,785\end{array}$ & $\begin{array}{r}3,928 \\
76 \\
450 \\
265 \\
259 \\
26 \\
255 \\
294 \\
358 \\
1,945\end{array}$ & $\begin{array}{r}51,298 \\
1,138 \\
4,884 \\
1,408 \\
6,738 \\
912 \\
7,516 \\
5,239 \\
10,321 \\
13,142\end{array}$ & $\begin{array}{r}49,992 \\
1,209 \\
5,063 \\
1,335 \\
6,224 \\
833 \\
8,302 \\
3,910 \\
10,184 \\
12,932\end{array}$ & $\begin{array}{r}119 \\
1 \\
25 \\
7 \\
7 \\
- \\
14\end{array}$ & $\begin{array}{r}97 \\
2 \\
6 \\
2 \\
4 \\
3 \\
8 \\
- \\
53 \\
19\end{array}$ & $\begin{array}{r}50 \\
- \\
3 \\
- \\
12 \\
1 \\
21 \\
2 \\
4 \\
7\end{array}$ & $\begin{array}{r}54 \\
1 \\
8 \\
- \\
12 \\
2 \\
9 \\
3 \\
5 \\
14\end{array}$ & $\begin{array}{r}23 \\
- \\
- \\
U \\
8 \\
- \\
9 \\
2 \\
2 \\
2\end{array}$ & $\begin{array}{r}45 \\
- \\
1 \\
U \\
13 \\
2 \\
6 \\
3 \\
10 \\
10\end{array}$ \\
\hline $\begin{array}{l}\text { E.S. CENTRAL } \\
\text { Ky. } \\
\text { Tenn. } \\
\text { Ala. } \\
\text { Miss. }\end{array}$ & $\begin{array}{l}682 \\
121 \\
220 \\
174 \\
167\end{array}$ & $\begin{array}{r}768 \\
99 \\
314 \\
206 \\
149\end{array}$ & $\begin{array}{r}18,234 \\
3,532 \\
5,654 \\
4,433 \\
4,615\end{array}$ & $\begin{array}{r}20,162 \\
3,216 \\
5,780 \\
6,359 \\
4,807\end{array}$ & $\begin{array}{r}14 \\
1 \\
2 \\
5 \\
6\end{array}$ & $\begin{array}{r}19 \\
1 \\
3 \\
8 \\
7\end{array}$ & $\begin{array}{r}21 \\
5 \\
11 \\
5 \\
-\end{array}$ & $\begin{array}{r}33 \\
10 \\
14 \\
1 \\
8\end{array}$ & $\begin{array}{r}14 \\
5 \\
8 \\
- \\
1\end{array}$ & $\begin{array}{r}23 \\
10 \\
11 \\
- \\
2\end{array}$ \\
\hline $\begin{array}{l}\text { W.S. CENTRAL } \\
\text { Ark. } \\
\text { La. } \\
\text { Okla. } \\
\text { Tex. }\end{array}$ & $\begin{array}{r}1,296 \\
81 \\
331 \\
67 \\
817\end{array}$ & $\begin{array}{r}1,423 \\
92 \\
214 \\
112 \\
1,005\end{array}$ & $\begin{array}{r}38,972 \\
3,145 \\
6,730 \\
3,872 \\
25,225\end{array}$ & $\begin{array}{r}42,007 \\
2,525 \\
7,647 \\
3,760 \\
28,075\end{array}$ & $\begin{array}{l}7 \\
2 \\
3 \\
2 \\
-\end{array}$ & $\begin{array}{r}30 \\
1 \\
6 \\
2 \\
21\end{array}$ & $\begin{array}{r}24 \\
1 \\
1 \\
8 \\
14\end{array}$ & $\begin{array}{r}34 \\
4 \\
3 \\
7 \\
20\end{array}$ & $\begin{array}{r}29 \\
- \\
13 \\
8 \\
8\end{array}$ & $\begin{array}{r}52 \\
4 \\
13 \\
3 \\
32\end{array}$ \\
\hline $\begin{array}{l}\text { MOUNTAIN } \\
\text { Mont. } \\
\text { Idaho } \\
\text { Wyo. } \\
\text { Colo. } \\
\text { N. Mex. } \\
\text { Ariz. } \\
\text { Utah } \\
\text { Nev. }\end{array}$ & $\begin{array}{r}510 \\
11 \\
7 \\
1 \\
109 \\
40 \\
202 \\
48 \\
92\end{array}$ & $\begin{array}{r}515 \\
7 \\
11 \\
2 \\
129 \\
50 \\
142 \\
57 \\
117\end{array}$ & $\begin{array}{r}13,134 \\
862 \\
703 \\
260 \\
1,116 \\
2,090 \\
5,717 \\
447 \\
1,939\end{array}$ & $\begin{array}{r}16,332 \\
601 \\
765 \\
310 \\
4,955 \\
2,024 \\
5,126 \\
1,027 \\
1,524\end{array}$ & $\begin{array}{r}44 \\
3 \\
5 \\
- \\
15 \\
8 \\
1 \\
10 \\
2\end{array}$ & $\begin{array}{r}31 \\
4 \\
3 \\
3 \\
8 \\
1 \\
2 \\
8 \\
2\end{array}$ & $\begin{array}{r}49 \\
3 \\
6 \\
1 \\
23 \\
3 \\
7 \\
3 \\
3\end{array}$ & $\begin{array}{r}53 \\
9 \\
9 \\
3 \\
16 \\
2 \\
12 \\
1 \\
1\end{array}$ & $\begin{array}{r}31 \\
- \\
- \\
- \\
16 \\
2 \\
7 \\
5 \\
1\end{array}$ & $\begin{array}{r}32 \\
- \\
4 \\
2 \\
7 \\
3 \\
13 \\
1 \\
2\end{array}$ \\
\hline $\begin{array}{l}\text { PACIFIC } \\
\text { Wash. } \\
\text { Oreg. } \\
\text { Calif. } \\
\text { Alaska } \\
\text { Hawaii }\end{array}$ & $\begin{array}{r}1,821 \\
201 \\
69 \\
1,526 \\
9 \\
16\end{array}$ & $\begin{array}{r}1,807 \\
196 \\
86 \\
1,457 \\
5 \\
63\end{array}$ & $\begin{array}{r}44,685 \\
5,599 \\
981 \\
36,912 \\
1,067 \\
126\end{array}$ & $\begin{array}{r}48,417 \\
5,272 \\
2,771 \\
37,927 \\
1,022 \\
1,425\end{array}$ & $\begin{array}{r}85 \\
N \\
3 \\
81 \\
- \\
1\end{array}$ & $\begin{array}{r}104 \\
U \\
3 \\
101 \\
- \\
-\end{array}$ & $\begin{array}{r}61 \\
15 \\
10 \\
34 \\
1 \\
1\end{array}$ & $\begin{array}{r}99 \\
25 \\
12 \\
54 \\
1 \\
7\end{array}$ & $\begin{array}{r}49 \\
13 \\
7 \\
27 \\
- \\
2\end{array}$ & $\begin{array}{r}77 \\
37 \\
18 \\
14 \\
1 \\
7\end{array}$ \\
\hline $\begin{array}{l}\text { Guam } \\
\text { P.R. } \\
\text { V.I. } \\
\text { Amer. Samoa } \\
\text { C.N.M.I. }\end{array}$ & $\begin{array}{r}9 \\
408 \\
2 \\
- \\
-\end{array}$ & $\begin{array}{r}13 \\
284 \\
18 \\
- \\
-\end{array}$ & $\begin{array}{r}2,090 \\
53 \\
U \\
50\end{array}$ & $\begin{array}{c}218 \\
U \\
U \\
U\end{array}$ & $\begin{array}{l}- \\
\bar{U} \\
\end{array}$ & $\begin{array}{l}- \\
- \\
\\
U\end{array}$ & $\begin{array}{l}\mathrm{N} \\
- \\
\bar{U} \\
-\end{array}$ & $\begin{array}{r}\mathrm{N} \\
3\end{array}$ & $\begin{array}{l}U \\
U \\
U \\
U\end{array}$ & $\begin{array}{l}U \\
U \\
U \\
U\end{array}$ \\
\hline
\end{tabular}

$\mathrm{N}$ : Not notifiable. $\quad$ U: Unavailable. $\quad$-: No reported cases. Health Laboratory Information System (PHLIS).

+ Chlamydia refers to genital infections caused by $C$. trachomatis. Totals reported to the Division of STD Prevention, NCHSTP.

$\S$ Updated monthly from reports to the Division of HIV/AIDS Prevention — Surveillance and Epidemiology, National Center for HIV, STD, and TB Prevention. Last update April 24, 2001 
TABLE II. (Cont'd) Provisional cases of selected notifiable diseases, United States, weeks ending May 26, 2001, and May 27, 2000 (21st Week)

\begin{tabular}{|c|c|c|c|c|c|c|c|c|c|}
\hline \multirow[b]{2}{*}{ Reporting Area } & \multicolumn{2}{|c|}{ Gonorrhea } & \multicolumn{2}{|c|}{$\begin{array}{c}\text { Hepatitis C; } \\
\text { Non-A, Non-B }\end{array}$} & \multicolumn{2}{|c|}{ Legionellosis } & \multirow{2}{*}{$\begin{array}{c}\text { Listeriosis } \\
\text { Cum. } \\
2001 \\
\end{array}$} & \multicolumn{2}{|c|}{$\begin{array}{c}\text { Lyme } \\
\text { Disease }\end{array}$} \\
\hline & $\begin{array}{l}\text { Cum. } \\
2001\end{array}$ & $\begin{array}{l}\text { Cum. } \\
2000\end{array}$ & $\begin{array}{l}\text { Cum. } \\
2001\end{array}$ & $\begin{array}{l}\text { Cum. } \\
2000\end{array}$ & $\begin{array}{c}\text { Cum. } \\
2001 \\
\end{array}$ & $\begin{array}{l}\text { Cum. } \\
2000 \\
\end{array}$ & & $\begin{array}{l}\text { Cum. } \\
2001 \\
\end{array}$ & $\begin{array}{l}\text { Cum. } \\
2000 \\
\end{array}$ \\
\hline UNITED STATES & 113,748 & 135,840 & 888 & 10,102 & 251 & 268 & 143 & 925 & 2,189 \\
\hline $\begin{array}{l}\text { NEW ENGLAND } \\
\text { Maine } \\
\text { N.H. } \\
\text { Vt. } \\
\text { Mass. } \\
\text { R.I. } \\
\text { Conn. }\end{array}$ & $\begin{array}{r}2,447 \\
56 \\
54 \\
31 \\
1,197 \\
274 \\
835\end{array}$ & $\begin{array}{r}2,589 \\
32 \\
38 \\
26 \\
1,028 \\
260 \\
1,205\end{array}$ & $\begin{array}{r}12 \\
- \\
- \\
5 \\
7 \\
- \\
-\end{array}$ & $\begin{array}{r}11 \\
- \\
- \\
3 \\
5 \\
3 \\
-\end{array}$ & $\begin{array}{r}15 \\
- \\
4 \\
4 \\
4 \\
1 \\
2\end{array}$ & $\begin{array}{r}19 \\
2 \\
2 \\
1 \\
9 \\
2 \\
3\end{array}$ & $\begin{array}{c}14 \\
- \\
- \\
- \\
8 \\
1 \\
5\end{array}$ & $\begin{array}{r}305 \\
- \\
45 \\
1 \\
61 \\
15 \\
183\end{array}$ & $\begin{array}{r}409 \\
- \\
31 \\
7 \\
148 \\
- \\
223\end{array}$ \\
\hline $\begin{array}{l}\text { MID. ATLANTIC } \\
\text { Upstate N.Y. } \\
\text { N.Y. City } \\
\text { N.J. } \\
\text { Pa. }\end{array}$ & $\begin{array}{r}11,928 \\
3,036 \\
4,255 \\
1,027 \\
3,610\end{array}$ & $\begin{array}{r}14,511 \\
2,451 \\
4,631 \\
2,838 \\
4,591\end{array}$ & $\begin{array}{r}30 \\
20 \\
- \\
- \\
10\end{array}$ & $\begin{array}{r}283 \\
11 \\
254 \\
18\end{array}$ & $\begin{array}{r}27 \\
17 \\
4 \\
4 \\
2\end{array}$ & $\begin{array}{r}66 \\
20 \\
9 \\
6 \\
31\end{array}$ & $\begin{array}{r}23 \\
10 \\
4 \\
6 \\
3\end{array}$ & $\begin{array}{r}362 \\
285 \\
1 \\
7 \\
69\end{array}$ & $\begin{array}{r}1,394 \\
423 \\
52 \\
428 \\
491\end{array}$ \\
\hline $\begin{array}{l}\text { E.N. CENTRAL } \\
\text { Ohio } \\
\text { Ind. } \\
\text { III. } \\
\text { Mich. } \\
\text { Wis. }\end{array}$ & $\begin{array}{r}19,123 \\
2,816 \\
2,414 \\
5,915 \\
6,818 \\
1,160\end{array}$ & $\begin{array}{r}27,348 \\
6,914 \\
2,373 \\
8,385 \\
6,838 \\
2,838\end{array}$ & $\begin{array}{r}92 \\
5 \\
1 \\
10 \\
76 \\
-\end{array}$ & $\begin{array}{r}105 \\
3 \\
- \\
10 \\
92\end{array}$ & $\begin{array}{r}69 \\
38 \\
6 \\
- \\
18 \\
7\end{array}$ & $\begin{array}{r}73 \\
32 \\
9 \\
7 \\
14 \\
11\end{array}$ & $\begin{array}{r}19 \\
4 \\
3 \\
- \\
11 \\
1\end{array}$ & $\begin{array}{r}21 \\
20 \\
1 \\
- \\
-\end{array}$ & $\begin{array}{r}90 \\
11 \\
1 \\
7 \\
4 \\
67\end{array}$ \\
\hline $\begin{array}{l}\text { W.N. CENTRAL } \\
\text { Minn. } \\
\text { lowa } \\
\text { Mo. } \\
\text { N. Dak. } \\
\text { S. Dak. } \\
\text { Nebr. } \\
\text { Kans. }\end{array}$ & $\begin{array}{r}5,256 \\
785 \\
392 \\
2,662 \\
13 \\
103 \\
271 \\
1,030\end{array}$ & $\begin{array}{r}6,582 \\
1,273 \\
422 \\
3,173 \\
25 \\
105 \\
548 \\
1,036\end{array}$ & $\begin{array}{r}288 \\
- \\
284 \\
- \\
- \\
1 \\
3\end{array}$ & $\begin{array}{r}223 \\
4 \\
1 \\
212 \\
- \\
- \\
2 \\
4\end{array}$ & $\begin{array}{r}18 \\
1 \\
4 \\
9 \\
- \\
- \\
3 \\
1\end{array}$ & $\begin{array}{r}14 \\
1 \\
3 \\
7 \\
- \\
1 \\
- \\
2\end{array}$ & $\begin{array}{l}3 \\
- \\
- \\
1 \\
- \\
- \\
1 \\
1\end{array}$ & $\begin{array}{r}34 \\
21 \\
3 \\
7 \\
- \\
- \\
1 \\
2\end{array}$ & $\begin{array}{r}35 \\
13 \\
- \\
12 \\
- \\
- \\
1 \\
9\end{array}$ \\
\hline $\begin{array}{l}\text { S. ATLANTIC } \\
\text { Del. } \\
\text { Md. } \\
\text { D.C. } \\
\text { Va. } \\
\text { W.Va. } \\
\text { N.C. } \\
\text { S.C. } \\
\text { Ga. } \\
\text { Fla. }\end{array}$ & \begin{tabular}{r|}
31,034 \\
613 \\
2,798 \\
1,190 \\
3,311 \\
224 \\
6,106 \\
3,798 \\
5,610 \\
7,384
\end{tabular} & $\begin{array}{r}34,917 \\
678 \\
3,456 \\
931 \\
4,042 \\
264 \\
6,877 \\
3,478 \\
6,241 \\
8,950\end{array}$ & $\begin{array}{r}47 \\
11 \\
- \\
- \\
5 \\
8 \\
3 \\
- \\
20\end{array}$ & $\begin{array}{r}32 \\
2 \\
2 \\
- \\
1 \\
4 \\
12 \\
- \\
1 \\
10\end{array}$ & $\begin{array}{r}42 \\
- \\
8 \\
2 \\
6 \\
\mathrm{~N} \\
4 \\
1 \\
2 \\
19\end{array}$ & $\begin{array}{r}44 \\
4 \\
10 \\
- \\
3 \\
N \\
6 \\
2 \\
4 \\
15\end{array}$ & $\begin{array}{r}25 \\
- \\
2 \\
- \\
4 \\
3 \\
- \\
2 \\
7 \\
7\end{array}$ & $\begin{array}{r}149 \\
104 \\
7 \\
7 \\
27 \\
1 \\
5 \\
1 \\
- \\
4\end{array}$ & $\begin{array}{r}202 \\
34 \\
127 \\
1 \\
18 \\
8 \\
8 \\
2 \\
- \\
4\end{array}$ \\
\hline $\begin{array}{l}\text { E.S. CENTRAL } \\
\text { Ky. } \\
\text { Tenn. } \\
\text { Ala. } \\
\text { Miss. }\end{array}$ & $\begin{array}{r}11,430 \\
1,376 \\
3,638 \\
3,516 \\
2,900\end{array}$ & $\begin{array}{r}14,247 \\
1,344 \\
4,430 \\
4,833 \\
3,640\end{array}$ & $\begin{array}{r}91 \\
3 \\
28 \\
2 \\
58\end{array}$ & $\begin{array}{r}190 \\
16 \\
41 \\
6 \\
127\end{array}$ & $\begin{array}{r}23 \\
6 \\
9 \\
6 \\
2\end{array}$ & $\begin{array}{l}8 \\
5 \\
1 \\
1 \\
1\end{array}$ & $\begin{array}{l}8 \\
2 \\
3 \\
3 \\
-\end{array}$ & $\begin{array}{l}4 \\
2 \\
2 \\
- \\
-\end{array}$ & $\begin{array}{l}9 \\
2 \\
5 \\
1 \\
1\end{array}$ \\
\hline $\begin{array}{l}\text { W.S. CENTRAL } \\
\text { Ark. } \\
\text { La. } \\
\text { Okla. } \\
\text { Tex. }\end{array}$ & $\begin{array}{r}18,755 \\
1,939 \\
4,606 \\
1,791 \\
10,419\end{array}$ & $\begin{array}{r}21,679 \\
1,341 \\
5,403 \\
1,658 \\
13,277\end{array}$ & $\begin{array}{r}151 \\
3 \\
64 \\
3 \\
81\end{array}$ & $\begin{array}{r}9,162 \\
2 \\
227 \\
2 \\
8,931\end{array}$ & $\begin{array}{l}4 \\
- \\
2 \\
2 \\
-\end{array}$ & $\begin{array}{r}11 \\
- \\
5 \\
1 \\
5\end{array}$ & $\begin{array}{l}4 \\
1 \\
- \\
- \\
3\end{array}$ & $\begin{array}{l}7 \\
- \\
1 \\
- \\
6\end{array}$ & $\begin{array}{r}18 \\
- \\
1 \\
- \\
17\end{array}$ \\
\hline $\begin{array}{l}\text { MOUNTAIN } \\
\text { Mont. } \\
\text { Idaho } \\
\text { Wyo. } \\
\text { Colo. } \\
\text { N. Mex. } \\
\text { Ariz. } \\
\text { Utah } \\
\text { Nev. }\end{array}$ & $\begin{array}{r}4,027 \\
43 \\
33 \\
17 \\
1,240 \\
347 \\
1,595 \\
41 \\
711\end{array}$ & $\begin{array}{r}4,187 \\
20 \\
36 \\
27 \\
1,337 \\
426 \\
1,678 \\
110 \\
553\end{array}$ & $\begin{array}{r}128 \\
- \\
1 \\
101 \\
10 \\
9 \\
4 \\
- \\
3\end{array}$ & $\begin{array}{r}27 \\
1 \\
- \\
1 \\
5 \\
6 \\
10 \\
- \\
4\end{array}$ & $\begin{array}{r}20 \\
- \\
- \\
1 \\
6 \\
1 \\
6 \\
4 \\
2\end{array}$ & $\begin{array}{r}15 \\
- \\
2 \\
- \\
6 \\
1 \\
2 \\
4 \\
-\end{array}$ & $\begin{array}{r}15 \\
- \\
1 \\
- \\
2 \\
3 \\
3 \\
1 \\
5\end{array}$ & $\begin{array}{l}4 \\
- \\
2 \\
1 \\
- \\
- \\
- \\
- \\
1\end{array}$ & $\begin{array}{l}1 \\
- \\
- \\
1 \\
- \\
- \\
- \\
-\end{array}$ \\
\hline $\begin{array}{l}\text { PACIFIC } \\
\text { Wash. } \\
\text { Oreg. } \\
\text { Calif. } \\
\text { Alaska } \\
\text { Hawaii }\end{array}$ & $\begin{array}{r}9,748 \\
1,199 \\
155 \\
8,236 \\
128 \\
30\end{array}$ & $\begin{array}{r}9,780 \\
916 \\
362 \\
8,193 \\
124 \\
185\end{array}$ & $\begin{array}{r}49 \\
12 \\
7 \\
30 \\
- \\
-\end{array}$ & $\begin{array}{r}69 \\
9 \\
14 \\
46 \\
-\end{array}$ & $\begin{array}{r}33 \\
6 \\
N \\
27 \\
- \\
-\end{array}$ & $\begin{array}{r}18 \\
8 \\
N \\
10 \\
- \\
-\end{array}$ & $\begin{array}{r}32 \\
2 \\
1 \\
29 \\
- \\
-\end{array}$ & $\begin{array}{r}39 \\
2 \\
3 \\
34 \\
- \\
\mathrm{N}\end{array}$ & $\begin{array}{r}31 \\
- \\
3 \\
27 \\
1 \\
N\end{array}$ \\
\hline $\begin{array}{l}\text { Guam } \\
\text { P.R. } \\
\text { V.I. } \\
\text { Amer. Samoa } \\
\text { C.N.M.I. }\end{array}$ & $\begin{array}{r}653 \\
6 \\
U \\
3\end{array}$ & $\begin{array}{r}22 \\
230 \\
- \\
U\end{array}$ & $\begin{array}{l}- \\
\overline{-} \\
\bar{u} \\
-\end{array}$ & $\begin{array}{l}1 \\
1 \\
\\
\end{array}$ & $\begin{array}{l}\overline{2} \\
\bar{U} \\
\end{array}$ & $\begin{array}{l}- \\
- \\
\\
U\end{array}$ & $\begin{array}{l}- \\
- \\
- \\
- \\
-\end{array}$ & $\begin{array}{l}\bar{N} \\
\bar{U} \\
-\end{array}$ & $\begin{array}{l}\bar{N} \\
\bar{U}\end{array}$ \\
\hline
\end{tabular}

$\mathrm{N}:$ Not notifiable.

U: Unavailable.

- : No reported cases. 
TABLE II. (Cont'd) Provisional cases of selected notifiable diseases, United States, weeks ending May 26, 2001, and May 27, 2000 (21st Week)

\begin{tabular}{|c|c|c|c|c|c|c|c|c|}
\hline \multirow[b]{3}{*}{ Reporting Area } & \multirow{2}{*}{\multicolumn{2}{|c|}{ Malaria }} & \multirow{2}{*}{\multicolumn{2}{|c|}{ Rabies, Animal }} & \multicolumn{4}{|c|}{ Salmonellosis* } \\
\hline & & & & & \multicolumn{2}{|c|}{ NETSS } & \multicolumn{2}{|c|}{ PHLIS } \\
\hline & $\begin{array}{l}\text { Cum. } \\
2001\end{array}$ & $\begin{array}{l}\text { Cum. } \\
2000\end{array}$ & $\begin{array}{l}\text { Cum. } \\
2001\end{array}$ & $\begin{array}{l}\text { Cum. } \\
2000\end{array}$ & $\begin{array}{l}\text { Cum. } \\
2001\end{array}$ & $\begin{array}{l}\text { Cum. } \\
2000\end{array}$ & $\begin{array}{l}\text { Cum. } \\
2001\end{array}$ & $\begin{array}{r}\text { Cum } \\
2000 \\
\end{array}$ \\
\hline UNITED STATES & 338 & 442 & 2,284 & 2,500 & 9,218 & 11,029 & 7,345 & 10,711 \\
\hline $\begin{array}{l}\text { NEW ENGLAND } \\
\text { Maine } \\
\text { N.H. } \\
\text { Vt. } \\
\text { Mass. } \\
\text { R.I. } \\
\text { Conn. }\end{array}$ & $\begin{array}{r}26 \\
3 \\
2 \\
- \\
6 \\
3 \\
12\end{array}$ & $\begin{array}{r}18 \\
2 \\
1 \\
2 \\
8 \\
3 \\
2\end{array}$ & $\begin{array}{r}241 \\
30 \\
7 \\
34 \\
74 \\
26 \\
70\end{array}$ & $\begin{array}{r}282 \\
60 \\
3 \\
22 \\
90 \\
19 \\
88\end{array}$ & $\begin{array}{r}747 \\
88 \\
55 \\
32 \\
421 \\
42 \\
109\end{array}$ & $\begin{array}{r}649 \\
48 \\
45 \\
45 \\
377 \\
25 \\
109\end{array}$ & $\begin{array}{r}666 \\
70 \\
42 \\
32 \\
320 \\
55 \\
147\end{array}$ & $\begin{array}{r}692 \\
33 \\
46 \\
53 \\
374 \\
51 \\
135\end{array}$ \\
\hline $\begin{array}{l}\text { MID. ATLANTIC } \\
\text { Upstate N.Y. } \\
\text { N.Y. City } \\
\text { N.J. } \\
\text { Pa. }\end{array}$ & $\begin{array}{r}62 \\
16 \\
33 \\
8 \\
5\end{array}$ & $\begin{array}{l}88 \\
20 \\
42 \\
13 \\
13\end{array}$ & $\begin{array}{r}301 \\
231 \\
5 \\
63 \\
2\end{array}$ & $\begin{array}{r}378 \\
261 \\
3 \\
60 \\
54\end{array}$ & $\begin{array}{r}927 \\
341 \\
301 \\
204 \\
81\end{array}$ & $\begin{array}{r}1,603 \\
350 \\
455 \\
447 \\
351\end{array}$ & $\begin{array}{r}1,144 \\
322 \\
362 \\
218 \\
242\end{array}$ & $\begin{array}{r}1,828 \\
480 \\
476 \\
347 \\
525\end{array}$ \\
\hline $\begin{array}{l}\text { E.N. CENTRAL } \\
\text { Ohio } \\
\text { Ind. } \\
\text { III. } \\
\text { Mich. } \\
\text { Wis. }\end{array}$ & $\begin{array}{r}41 \\
9 \\
9 \\
1 \\
15 \\
7\end{array}$ & $\begin{array}{r}56 \\
5 \\
2 \\
33 \\
10 \\
6\end{array}$ & $\begin{array}{r}14 \\
2 \\
1 \\
2 \\
9\end{array}$ & $\begin{array}{r}25 \\
4 \\
- \\
1 \\
13 \\
7\end{array}$ & $\begin{array}{r}1,280 \\
472 \\
136 \\
281 \\
244 \\
147\end{array}$ & $\begin{array}{r}1,642 \\
373 \\
167 \\
519 \\
317 \\
266\end{array}$ & $\begin{array}{r}1,047 \\
408 \\
112 \\
179 \\
226 \\
122\end{array}$ & $\begin{array}{r}1,564 \\
372 \\
186 \\
555 \\
340 \\
111\end{array}$ \\
\hline $\begin{array}{l}\text { W.N. CENTRAL } \\
\text { Minn. } \\
\text { lowa } \\
\text { Mo. } \\
\text { N. Dak. } \\
\text { S. Dak. } \\
\text { Nebr. } \\
\text { Kans. }\end{array}$ & $\begin{array}{r}14 \\
6 \\
1 \\
3 \\
- \\
- \\
2 \\
2\end{array}$ & $\begin{array}{r}22 \\
7 \\
1 \\
3 \\
2 \\
- \\
3 \\
6\end{array}$ & $\begin{array}{r}128 \\
15 \\
22 \\
13 \\
17 \\
15 \\
1 \\
45\end{array}$ & $\begin{array}{r}227 \\
32 \\
33 \\
10 \\
57 \\
48 \\
47\end{array}$ & $\begin{array}{r}552 \\
158 \\
85 \\
147 \\
1 \\
40 \\
44 \\
77\end{array}$ & $\begin{array}{r}608 \\
66 \\
80 \\
227 \\
15 \\
25 \\
71 \\
124\end{array}$ & $\begin{array}{r}598 \\
207 \\
89 \\
194 \\
18 \\
31 \\
- \\
59\end{array}$ & $\begin{array}{r}785 \\
226 \\
88 \\
267 \\
26 \\
39 \\
48 \\
91\end{array}$ \\
\hline $\begin{array}{l}\text { S. ATLANTIC } \\
\text { Del. } \\
\text { Md. } \\
\text { D.C. } \\
\text { Va. } \\
\text { W. Va. } \\
\text { N.C. } \\
\text { S.C. } \\
\text { Ga. } \\
\text { Fla. }\end{array}$ & $\begin{array}{r}89 \\
1 \\
35 \\
4 \\
20 \\
1 \\
2 \\
4 \\
3 \\
19\end{array}$ & $\begin{array}{r}93 \\
2 \\
35 \\
1 \\
23 \\
- \\
9 \\
1 \\
4 \\
18\end{array}$ & $\begin{array}{r}818 \\
12 \\
97 \\
168 \\
54 \\
239 \\
50 \\
110 \\
88\end{array}$ & $\begin{array}{r}865 \\
18 \\
165 \\
220 \\
220 \\
51 \\
217 \\
49 \\
91 \\
54\end{array}$ & $\begin{array}{r}2,320 \\
25 \\
240 \\
26 \\
391 \\
33 \\
373 \\
269 \\
319 \\
644\end{array}$ & $\begin{array}{r}1,861 \\
35 \\
257 \\
19 \\
243 \\
46 \\
274 \\
154 \\
308 \\
525\end{array}$ & $\begin{array}{r}1,436 \\
27 \\
255 \\
U \\
314 \\
33 \\
194 \\
239 \\
301 \\
73\end{array}$ & $\begin{array}{r}1,586 \\
39 \\
290 \\
U \\
252 \\
42 \\
232 \\
133 \\
447 \\
151\end{array}$ \\
\hline $\begin{array}{l}\text { E.S. CENTRAL } \\
\text { Ky. } \\
\text { Tenn. } \\
\text { Ala. } \\
\text { Miss. }\end{array}$ & $\begin{array}{r}10 \\
2 \\
5 \\
3 \\
-\end{array}$ & $\begin{array}{r}15 \\
2 \\
5 \\
7 \\
1\end{array}$ & $\begin{array}{l}79 \\
10 \\
57 \\
12\end{array}$ & $\begin{array}{l}74 \\
10 \\
45 \\
19 \\
-\end{array}$ & $\begin{array}{r}528 \\
97 \\
143 \\
192 \\
96\end{array}$ & $\begin{array}{l}529 \\
113 \\
131 \\
156 \\
129\end{array}$ & $\begin{array}{r}315 \\
67 \\
115 \\
109 \\
24\end{array}$ & $\begin{array}{r}431 \\
81 \\
195 \\
129 \\
26\end{array}$ \\
\hline $\begin{array}{l}\text { W.S. CENTRAL } \\
\text { Ark. } \\
\text { La. } \\
\text { Okla. } \\
\text { Tex. }\end{array}$ & $\begin{array}{l}5 \\
2 \\
1 \\
1 \\
1\end{array}$ & $\begin{array}{r}23 \\
1 \\
4 \\
1 \\
17\end{array}$ & $\begin{array}{r}479 \\
- \\
37 \\
442\end{array}$ & $\begin{array}{r}436 \\
- \\
30 \\
406\end{array}$ & $\begin{array}{r}896 \\
122 \\
208 \\
75 \\
491\end{array}$ & $\begin{array}{r}1,220 \\
116 \\
211 \\
104 \\
789\end{array}$ & $\begin{array}{r}498 \\
79 \\
168 \\
53 \\
198\end{array}$ & $\begin{array}{r}733 \\
83 \\
155 \\
89 \\
406\end{array}$ \\
\hline $\begin{array}{l}\text { MOUNTAIN } \\
\text { Mont. } \\
\text { Idaho } \\
\text { Wyo. } \\
\text { Colo. } \\
\text { N. Mex. } \\
\text { Ariz. } \\
\text { Utah } \\
\text { Nev. }\end{array}$ & $\begin{array}{r}19 \\
2 \\
2 \\
- \\
9 \\
1 \\
1 \\
2 \\
2\end{array}$ & $\begin{array}{r}19 \\
1 \\
- \\
- \\
10 \\
- \\
2 \\
3 \\
3\end{array}$ & $\begin{array}{r}90 \\
14 \\
- \\
16 \\
- \\
3 \\
57 \\
- \\
-\end{array}$ & $\begin{array}{r}93 \\
24 \\
1 \\
27 \\
- \\
6 \\
34 \\
1 \\
-\end{array}$ & $\begin{array}{r}636 \\
25 \\
32 \\
25 \\
187 \\
84 \\
169 \\
68 \\
46\end{array}$ & $\begin{array}{r}928 \\
40 \\
49 \\
21 \\
288 \\
82 \\
210 \\
141 \\
97\end{array}$ & $\begin{array}{r}524 \\
- \\
4 \\
16 \\
189 \\
66 \\
158 \\
68 \\
23\end{array}$ & $\begin{array}{r}862 \\
- \\
47 \\
18 \\
272 \\
73 \\
225 \\
134 \\
93\end{array}$ \\
\hline $\begin{array}{l}\text { PACIFIC } \\
\text { Wash. } \\
\text { Oreg. } \\
\text { Calif. } \\
\text { Alaska } \\
\text { Hawaii }\end{array}$ & $\begin{array}{r}72 \\
2 \\
4 \\
62 \\
1 \\
3\end{array}$ & $\begin{array}{r}108 \\
7 \\
21 \\
77 \\
- \\
3\end{array}$ & $\begin{array}{r}134 \\
- \\
10 \overline{1} \\
33 \\
-\end{array}$ & $\begin{array}{r}120 \\
- \\
9 \overline{-} \\
23 \\
-\end{array}$ & $\begin{array}{r}1,332 \\
148 \\
62 \\
1,070 \\
16 \\
36\end{array}$ & $\begin{array}{r}1,989 \\
150 \\
126 \\
1,623 \\
22 \\
68\end{array}$ & $\begin{array}{r}1,117 \\
205 \\
92 \\
704 \\
2 \\
114\end{array}$ & $\begin{array}{r}2,230 \\
243 \\
161 \\
1,741 \\
19 \\
66\end{array}$ \\
\hline $\begin{array}{l}\text { Guam } \\
\text { P.R. } \\
\text { V.I. } \\
\text { Amer. Samoa } \\
\text { C.N.M.I. }\end{array}$ & $\begin{array}{l}- \\
\\
\end{array}$ & $\begin{array}{l}\overline{3} \\
\bar{U} \\
U\end{array}$ & $\begin{array}{r}61 \\
\bar{U}\end{array}$ & $\begin{array}{r}25 \\
\bar{U} \\
\\
U\end{array}$ & $10 \overline{-}$ & $\begin{array}{r}9 \\
142\end{array}$ & $\begin{array}{l}U \\
U \\
U\end{array}$ & $\begin{array}{l}U \\
U \\
U\end{array}$ \\
\hline
\end{tabular}

$\mathrm{N}$ : Not notifiable. U: Unavailable.

-: No reported cases.

* Individual cases can be reported through both the National Electronic Telecommunications System for Surveillance (NETSS) and the Public Health Laboratory Information System (PHLIS). 
TABLE II. (Cont'd) Provisional cases of selected notifiable diseases, United States, weeks ending May 26, 2001, and May 27, 2000 (21st Week)

\begin{tabular}{|c|c|c|c|c|c|c|c|c|}
\hline \multirow[b]{3}{*}{ Reporting Area } & \multicolumn{4}{|c|}{ Shigellosis* } & \multirow{2}{*}{\multicolumn{2}{|c|}{$\begin{array}{c}\text { Syphilis } \\
\text { (Primary \& Secondary) }\end{array}$}} & \multirow{2}{*}{\multicolumn{2}{|c|}{ Tuberculosis }} \\
\hline & \multicolumn{2}{|c|}{ NETSS } & \multicolumn{2}{|c|}{ PHLIS } & & & & \\
\hline & $\begin{array}{l}\text { Cum. } \\
2001\end{array}$ & $\begin{array}{l}\text { Cum. } \\
2000\end{array}$ & $\begin{array}{l}\text { Cum. } \\
2001\end{array}$ & $\begin{array}{c}\text { Cum. } \\
2000\end{array}$ & $\begin{array}{c}\text { Cum. } \\
2001\end{array}$ & $\begin{array}{c}\text { Cum. } \\
2000\end{array}$ & $\begin{array}{c}\text { Cum. } \\
2001\end{array}$ & $\begin{array}{l}\text { Cum. } \\
2000\end{array}$ \\
\hline UNITED STATES & 4,448 & 6,970 & 2,147 & 4,427 & 1,979 & 2,564 & 4,036 & 5,015 \\
\hline $\begin{array}{l}\text { NEW ENGLAND } \\
\text { Maine } \\
\text { N.H. } \\
\text { Vt. } \\
\text { Mass. } \\
\text { R.I. } \\
\text { Conn. }\end{array}$ & $\begin{array}{r}71 \\
3 \\
1 \\
3 \\
47 \\
6 \\
6 \\
11\end{array}$ & $\begin{array}{r}117 \\
4 \\
1 \\
1 \\
79 \\
10 \\
22\end{array}$ & $\begin{array}{r}67 \\
1 \\
1 \\
1 \\
39 \\
9 \\
16\end{array}$ & $\begin{array}{r}97 \\
- \\
4 \\
- \\
62 \\
10 \\
21\end{array}$ & $\begin{array}{r}18 \\
- \\
1 \\
1 \\
11 \\
1 \\
4\end{array}$ & $\begin{array}{r}31 \\
1 \\
1 \\
- \\
23 \\
1 \\
5\end{array}$ & $\begin{array}{r}150 \\
5 \\
7 \\
2 \\
90 \\
13 \\
33\end{array}$ & $\begin{array}{r}144 \\
3 \\
3 \\
2 \\
88 \\
12 \\
36\end{array}$ \\
\hline $\begin{array}{l}\text { MID. ATLANTIC } \\
\text { Upstate N.Y. } \\
\text { N.Y. City } \\
\text { N.J. } \\
\text { Pa. }\end{array}$ & $\begin{array}{r}364 \\
162 \\
125 \\
40 \\
37\end{array}$ & $\begin{array}{r}1,055 \\
355 \\
503 \\
120 \\
77\end{array}$ & $\begin{array}{r}320 \\
14 \\
174 \\
67 \\
65\end{array}$ & $\begin{array}{r}646 \\
143 \\
321 \\
93 \\
89\end{array}$ & $\begin{array}{r}137 \\
4 \\
85 \\
29 \\
19\end{array}$ & $\begin{array}{r}117 \\
5 \\
50 \\
26 \\
36\end{array}$ & $\begin{array}{r}817 \\
117 \\
433 \\
188 \\
79\end{array}$ & $\begin{array}{r}852 \\
110 \\
471 \\
198 \\
73\end{array}$ \\
\hline $\begin{array}{l}\text { E.N. CENTRAL } \\
\text { Ohio } \\
\text { Ind. } \\
\text { IIl. } \\
\text { Mich. } \\
\text { Wis. }\end{array}$ & $\begin{array}{r}636 \\
235 \\
106 \\
141 \\
124 \\
30\end{array}$ & $\begin{array}{r}1,205 \\
88 \\
249 \\
390 \\
329 \\
149\end{array}$ & $\begin{array}{r}330 \\
130 \\
17 \\
84 \\
86 \\
13\end{array}$ & $\begin{array}{r}759 \\
74 \\
42 \\
318 \\
297 \\
28\end{array}$ & $\begin{array}{r}294 \\
29 \\
70 \\
82 \\
104 \\
9\end{array}$ & $\begin{array}{r}555 \\
28 \\
187 \\
195 \\
119 \\
26\end{array}$ & $\begin{array}{r}439 \\
65 \\
28 \\
237 \\
79 \\
30\end{array}$ & $\begin{array}{r}506 \\
114 \\
51 \\
232 \\
73 \\
36\end{array}$ \\
\hline $\begin{array}{l}\text { W.N. CENTRAL } \\
\text { Minn. } \\
\text { lowa } \\
\text { Mo. } \\
\text { N. Dak. } \\
\text { S. Dak. } \\
\text { Nebr. } \\
\text { Kans. }\end{array}$ & $\begin{array}{r}513 \\
181 \\
92 \\
114 \\
9 \\
49 \\
29 \\
39\end{array}$ & $\begin{array}{r}531 \\
91 \\
132 \\
243 \\
2 \\
2 \\
23 \\
23 \\
38\end{array}$ & $\begin{array}{r}398 \\
199 \\
79 \\
69 \\
1 \\
33 \\
- \\
17\end{array}$ & $\begin{array}{r}462 \\
144 \\
128 \\
151 \\
1 \\
1 \\
11 \\
26\end{array}$ & $\begin{array}{r}24 \\
12 \\
1 \\
6 \\
- \\
- \\
- \\
5\end{array}$ & $\begin{array}{r}38 \\
4 \\
10 \\
19 \\
- \\
- \\
2 \\
3\end{array}$ & $\begin{array}{r}161 \\
88 \\
9 \\
43 \\
- \\
6 \\
15 \\
-\end{array}$ & $\begin{array}{r}199 \\
66 \\
13 \\
76 \\
- \\
9 \\
9 \\
26\end{array}$ \\
\hline $\begin{array}{l}\text { S. ATLANTIC } \\
\text { Del. } \\
\text { Md. } \\
\text { D.C. } \\
\text { Va. } \\
\text { W. Va. } \\
\text { N.C. } \\
\text { S.C. } \\
\text { Ga. } \\
\text { Fla. }\end{array}$ & $\begin{array}{r}718 \\
4 \\
45 \\
21 \\
53 \\
4 \\
151 \\
67 \\
86 \\
287\end{array}$ & $\begin{array}{r}782 \\
5 \\
37 \\
8 \\
66 \\
3 \\
49 \\
27 \\
97 \\
490\end{array}$ & $\begin{array}{r}219 \\
4 \\
23 \\
U \\
26 \\
6 \\
70 \\
35 \\
51 \\
4\end{array}$ & $\begin{array}{r}306 \\
5 \\
13 \\
U \\
85 \\
2 \\
26 \\
43 \\
81 \\
51\end{array}$ & $\begin{array}{r}795 \\
4 \\
92 \\
16 \\
55 \\
- \\
192 \\
109 \\
109 \\
218\end{array}$ & $\begin{array}{r}838 \\
4 \\
130 \\
19 \\
54 \\
1 \\
240 \\
89 \\
146 \\
155\end{array}$ & $\begin{array}{r}753 \\
- \\
74 \\
15 \\
83 \\
11 \\
103 \\
37 \\
163 \\
267\end{array}$ & $\begin{array}{r}841 \\
2 \\
91 \\
1 \\
106 \\
15 \\
119 \\
30 \\
192 \\
285\end{array}$ \\
\hline $\begin{array}{l}\text { E.S. CENTRAL } \\
\text { Ky. } \\
\text { Tenn. } \\
\text { Ala. } \\
\text { Miss. }\end{array}$ & $\begin{array}{r}408 \\
144 \\
39 \\
108 \\
117\end{array}$ & $\begin{array}{r}332 \\
76 \\
161 \\
15 \\
80\end{array}$ & $\begin{array}{r}164 \\
50 \\
28 \\
78 \\
8\end{array}$ & $\begin{array}{r}241 \\
36 \\
185 \\
17 \\
3\end{array}$ & $\begin{array}{r}223 \\
18 \\
126 \\
38 \\
41\end{array}$ & $\begin{array}{r}380 \\
42 \\
239 \\
46 \\
53\end{array}$ & $\begin{array}{r}256 \\
38 \\
69 \\
116 \\
33\end{array}$ & $\begin{array}{r}363 \\
41 \\
138 \\
120 \\
64\end{array}$ \\
\hline $\begin{array}{l}\text { W.S. CENTRAL } \\
\text { Ark. } \\
\text { La. } \\
\text { Okla. } \\
\text { Tex. }\end{array}$ & $\begin{array}{r}785 \\
235 \\
87 \\
13 \\
450\end{array}$ & $\begin{array}{r}1,228 \\
77 \\
110 \\
23 \\
1,018\end{array}$ & $\begin{array}{r}349 \\
144 \\
71 \\
2 \\
132\end{array}$ & $\begin{array}{r}371 \\
24 \\
58 \\
14 \\
275\end{array}$ & $\begin{array}{r}261 \\
18 \\
55 \\
32 \\
156\end{array}$ & $\begin{array}{r}350 \\
45 \\
81 \\
61 \\
163\end{array}$ & $\begin{array}{r}489 \\
51 \\
- \\
51 \\
387\end{array}$ & $\begin{array}{r}805 \\
73 \\
64 \\
50 \\
618\end{array}$ \\
\hline $\begin{array}{l}\text { MOUNTAIN } \\
\text { Mont. } \\
\text { Idaho } \\
\text { Wyo. } \\
\text { Colo. } \\
\text { N. Mex. } \\
\text { Ariz. } \\
\text { Utah } \\
\text { Nev. }\end{array}$ & $\begin{array}{r}278 \\
- \\
14 \\
- \\
60 \\
49 \\
117 \\
18 \\
20\end{array}$ & $\begin{array}{r}364 \\
3 \\
28 \\
2 \\
69 \\
36 \\
128 \\
32 \\
66\end{array}$ & $\begin{array}{r}172 \\
- \\
- \\
- \\
49 \\
29 \\
69 \\
17 \\
8\end{array}$ & $\begin{array}{r}231 \\
- \\
19 \\
2 \\
30 \\
21 \\
77 \\
35 \\
47\end{array}$ & $\begin{array}{r}83 \\
- \\
- \\
- \\
15 \\
6 \\
52 \\
6 \\
4\end{array}$ & $\begin{array}{r}84 \\
- \\
- \\
1 \\
5 \\
8 \\
68 \\
- \\
2\end{array}$ & $\begin{array}{r}151 \\
- \\
4 \\
- \\
45 \\
11 \\
54 \\
6 \\
31\end{array}$ & $\begin{array}{r}189 \\
6 \\
4 \\
1 \\
24 \\
21 \\
69 \\
20 \\
44\end{array}$ \\
\hline $\begin{array}{l}\text { PACIFIC } \\
\text { Wash. } \\
\text { Oreg. } \\
\text { Calif. } \\
\text { Alaska } \\
\text { Hawaii }\end{array}$ & $\begin{array}{r}675 \\
67 \\
21 \\
580 \\
2 \\
5\end{array}$ & $\begin{array}{r}1,356 \\
293 \\
92 \\
950 \\
6 \\
15\end{array}$ & $\begin{array}{r}128 \\
76 \\
36 \\
- \\
1 \\
15\end{array}$ & $\begin{array}{r}1,314 \\
278 \\
56 \\
965 \\
3 \\
12\end{array}$ & $\begin{array}{r}144 \\
23 \\
2 \\
118 \\
- \\
1\end{array}$ & $\begin{array}{r}171 \\
23 \\
6 \\
141 \\
- \\
1\end{array}$ & $\begin{array}{r}820 \\
82 \\
35 \\
680 \\
17 \\
6\end{array}$ & $\begin{array}{r}1,116 \\
92 \\
33 \\
906 \\
37 \\
48\end{array}$ \\
\hline $\begin{array}{l}\text { Guam } \\
\text { P.R. } \\
\text { V.I. } \\
\text { Amer. Samoa } \\
\text { C.N.M.I. }\end{array}$ & $\begin{array}{l}- \\
7 \\
- \\
\\
4\end{array}$ & $\begin{array}{l}18 \\
14 \\
- \\
\cup \\
U\end{array}$ & $\begin{array}{l}U \\
\cup \\
\cup \\
\cup\end{array}$ & $\begin{array}{l}U \\
\cup \\
U \\
U\end{array}$ & $\begin{array}{r}136 \\
\bar{U} \\
-\end{array}$ & $\begin{array}{r}2 \\
78 \\
- \\
\cup \\
U\end{array}$ & $\begin{array}{r}58 \\
- \\
U \\
15\end{array}$ & $\begin{array}{r}26 \\
61 \\
- \\
U \\
U\end{array}$ \\
\hline
\end{tabular}

$\mathrm{N}$ : Not notifiable.

*Individual cases can be reported through both the National Electronic Telecommunications System for Surveillance (NETSS) and the Public Health Laboratory Information System (PHLIS). 
TABLE III. Provisional cases of selected notifiable diseases preventable by vaccination, United States, weeks ending May 26, 2001, and May 27, 2000 (21st Week)

\begin{tabular}{|c|c|c|c|c|c|c|c|c|c|c|c|c|}
\hline \multirow[b]{3}{*}{ Reporting Area } & \multirow{2}{*}{\multicolumn{2}{|c|}{$\begin{array}{c}\text { H. influenzae, } \\
\text { Invasive }\end{array}$}} & \multicolumn{4}{|c|}{ Hepatitis (Viral), By Type } & \multicolumn{6}{|c|}{ Measles (Rubeola) } \\
\hline & & & \multicolumn{2}{|c|}{ A } & \multicolumn{2}{|c|}{ B } & \multicolumn{2}{|c|}{ Indigenous } & \multicolumn{2}{|c|}{ Imported* } & \multicolumn{2}{|c|}{ Total } \\
\hline & $\begin{array}{l}\text { Cum. } \\
2001^{+} \\
\end{array}$ & $\begin{array}{l}\text { Cum. } \\
2000\end{array}$ & $\begin{array}{l}\text { Cum. } \\
2001 \\
\end{array}$ & $\begin{array}{l}\text { Cum. } \\
2000 \\
\end{array}$ & $\begin{array}{l}\text { Cum. } \\
2001\end{array}$ & $\begin{array}{l}\text { Cum. } \\
2000\end{array}$ & 2001 & $\begin{array}{l}\text { Cum. } \\
2001\end{array}$ & 2001 & $\begin{array}{l}\text { Cum. } \\
2001\end{array}$ & $\begin{array}{l}\text { Cum. } \\
2001\end{array}$ & $\begin{array}{l}\text { Cum. } \\
2000\end{array}$ \\
\hline UNITED STATES & 572 & 560 & 3,617 & 5,260 & 2,382 & 2,666 & - & 24 & - & 20 & 44 & 32 \\
\hline $\begin{array}{l}\text { NEW ENGLAND } \\
\text { Maine } \\
\text { N.H. } \\
\text { Vt. } \\
\text { Mass. } \\
\text { R.I. } \\
\text { Conn. }\end{array}$ & $\begin{array}{r}19 \\
1 \\
- \\
1 \\
16 \\
1 \\
-\end{array}$ & $\begin{array}{r}44 \\
1 \\
6 \\
3 \\
26 \\
1 \\
7\end{array}$ & $\begin{array}{r}170 \\
5 \\
5 \\
3 \\
48 \\
8 \\
101\end{array}$ & $\begin{array}{r}127 \\
7 \\
11 \\
3 \\
51 \\
6 \\
49\end{array}$ & $\begin{array}{r}39 \\
4 \\
9 \\
2 \\
3 \\
9 \\
12\end{array}$ & $\begin{array}{r}44 \\
5 \\
8 \\
3 \\
2 \\
9 \\
17\end{array}$ & $\begin{array}{l}\overline{-} \\
- \\
\overline{-} \\
\overline{-}\end{array}$ & $\begin{array}{l}3 \\
- \\
- \\
1 \\
2 \\
- \\
-\end{array}$ & $\begin{array}{l}- \\
\\
- \\
- \\
-\end{array}$ & $\begin{array}{l}1 \\
- \\
- \\
- \\
1 \\
- \\
-\end{array}$ & $\begin{array}{l}4 \\
- \\
- \\
1 \\
3 \\
- \\
-\end{array}$ & $\begin{array}{l}- \\
- \\
- \\
- \\
- \\
-\end{array}$ \\
\hline $\begin{array}{l}\text { MID. ATLANTIC } \\
\text { Upstate N.Y. } \\
\text { N.Y. City } \\
\text { N.J. } \\
\text { Pa. }\end{array}$ & $\begin{array}{r}70 \\
27 \\
23 \\
19 \\
1\end{array}$ & $\begin{array}{r}86 \\
32 \\
27 \\
22 \\
5\end{array}$ & $\begin{array}{r}326 \\
103 \\
133 \\
70 \\
20\end{array}$ & $\begin{array}{r}494 \\
94 \\
201 \\
82 \\
117\end{array}$ & $\begin{array}{r}331 \\
56 \\
182 \\
64 \\
29\end{array}$ & $\begin{array}{r}481 \\
50 \\
231 \\
86 \\
114\end{array}$ & $\begin{array}{l}- \\
\overline{-} \\
\bar{u}\end{array}$ & $\begin{array}{l}2 \\
1 \\
- \\
- \\
1\end{array}$ & $\begin{array}{l}- \\
- \\
- \\
\bar{U}\end{array}$ & $\begin{array}{l}5 \\
4 \\
- \\
1 \\
-\end{array}$ & $\begin{array}{l}7 \\
5 \\
- \\
1 \\
1\end{array}$ & $\begin{array}{r}10 \\
- \\
10 \\
- \\
-\end{array}$ \\
\hline $\begin{array}{l}\text { E.N. CENTRAL } \\
\text { Ohio } \\
\text { Ind. } \\
\text { IIII. } \\
\text { Mich. } \\
\text { Wis. }\end{array}$ & $\begin{array}{r}74 \\
37 \\
19 \\
10 \\
4 \\
4\end{array}$ & $\begin{array}{r}87 \\
27 \\
10 \\
31 \\
7 \\
72\end{array}$ & $\begin{array}{r}418 \\
100 \\
39 \\
121 \\
143 \\
15\end{array}$ & $\begin{array}{r}697 \\
127 \\
18 \\
295 \\
214 \\
43\end{array}$ & $\begin{array}{r}294 \\
53 \\
12 \\
24 \\
205 \\
-\end{array}$ & $\begin{array}{r}282 \\
46 \\
20 \\
36 \\
167 \\
13\end{array}$ & $\begin{array}{l}- \\
\overline{-} \\
\bar{u} \\
\bar{U}\end{array}$ & $\begin{array}{l}- \\
- \\
- \\
- \\
- \\
-\end{array}$ & $\begin{array}{l}- \\
- \\
- \\
- \\
\bar{U}\end{array}$ & $\begin{array}{r}10 \\
3 \\
4 \\
3 \\
- \\
-\end{array}$ & $\begin{array}{r}10 \\
3 \\
4 \\
3 \\
- \\
-\end{array}$ & $\begin{array}{l}3 \\
2 \\
- \\
- \\
1 \\
-\end{array}$ \\
\hline $\begin{array}{l}\text { W.N. CENTRAL } \\
\text { Minn. } \\
\text { lowa } \\
\text { Mo. } \\
\text { N. Dak. } \\
\text { S.Dak. } \\
\text { Nebr. } \\
\text { Kans. }\end{array}$ & $\begin{array}{r}22 \\
11 \\
- \\
9 \\
- \\
\overline{1} \\
1\end{array}$ & $\begin{array}{r}27 \\
15 \\
- \\
8 \\
1 \\
- \\
2 \\
1\end{array}$ & $\begin{array}{r}163 \\
12 \\
16 \\
44 \\
- \\
1 \\
21 \\
69\end{array}$ & $\begin{array}{r}392 \\
103 \\
38 \\
180 \\
- \\
- \\
17 \\
54\end{array}$ & $\begin{array}{r}87 \\
10 \\
9 \\
47 \\
- \\
1 \\
9 \\
11\end{array}$ & $\begin{array}{r}113 \\
14 \\
14 \\
57 \\
2 \\
- \\
18 \\
8\end{array}$ & $\begin{array}{l}- \\
- \\
\bar{u} \\
- \\
-\end{array}$ & $\begin{array}{l}4 \\
2 \\
- \\
2 \\
- \\
- \\
- \\
-\end{array}$ & $\begin{array}{l}- \\
- \\
- \\
\bar{U} \\
- \\
-\end{array}$ & $\begin{array}{l}- \\
\overline{-} \\
- \\
- \\
- \\
- \\
-\end{array}$ & $\begin{array}{l}4 \\
2 \\
- \\
2 \\
- \\
- \\
- \\
-\end{array}$ & $\begin{array}{l}- \\
- \\
- \\
- \\
- \\
-\end{array}$ \\
\hline $\begin{array}{l}\text { S. ATLANTIC } \\
\text { Del. } \\
\text { Md. } \\
\text { D.C. } \\
\text { Va. } \\
\text { W.Va. } \\
\text { N.C. } \\
\text { S.C. } \\
\text { Ga. } \\
\text { Fla. }\end{array}$ & $\begin{array}{r}190 \\
- \\
43 \\
- \\
14 \\
4 \\
23 \\
5 \\
50 \\
51\end{array}$ & $\begin{array}{r}33 \\
- \\
27 \\
4 \\
10 \\
3 \\
38 \\
17\end{array}$ & $\begin{array}{r}105 \\
18 \\
55 \\
2 \\
49 \\
23 \\
273 \\
207\end{array}$ & $\begin{array}{r}509 \\
8 \\
57 \\
3 \\
64 \\
38 \\
84 \\
16 \\
74 \\
165\end{array}$ & $\begin{array}{r}59 \\
3 \\
54 \\
12 \\
99 \\
6 \\
136 \\
152\end{array}$ & $\begin{array}{r}436 \\
7 \\
57 \\
5 \\
60 \\
4 \\
109 \\
3 \\
75 \\
116\end{array}$ & $\begin{array}{l}\overline{-} \\
- \\
- \\
\overline{-} \\
\overline{-} \\
-\end{array}$ & $\begin{array}{l}3 \\
- \\
2 \\
- \\
- \\
- \\
- \\
- \\
1 \\
-\end{array}$ & $\begin{array}{l}\bar{U} \\
- \\
- \\
- \\
- \\
- \\
- \\
-\end{array}$ & $\begin{array}{l}1 \\
- \\
- \\
- \\
- \\
- \\
-\end{array}$ & $\begin{array}{l}3 \\
- \\
- \\
- \\
- \\
- \\
1 \\
-\end{array}$ & $\begin{array}{l}- \\
- \\
- \\
- \\
- \\
- \\
-\end{array}$ \\
\hline $\begin{array}{l}\text { E.S. CENTRAL } \\
\text { Ky. } \\
\text { Tenn. } \\
\text { Ala. } \\
\text { Miss. }\end{array}$ & $\begin{array}{r}45 \\
2 \\
20 \\
22 \\
1\end{array}$ & $\begin{array}{r}27 \\
10 \\
11 \\
4 \\
2\end{array}$ & $\begin{array}{r}131 \\
19 \\
59 \\
47 \\
6\end{array}$ & $\begin{array}{r}216 \\
22 \\
81 \\
26 \\
87\end{array}$ & $\begin{array}{r}151 \\
17 \\
58 \\
39 \\
37\end{array}$ & $\begin{array}{r}187 \\
38 \\
79 \\
23 \\
47\end{array}$ & $\begin{array}{l}- \\
\overline{-} \\
\bar{U}\end{array}$ & $\begin{array}{l}2 \\
2 \\
- \\
- \\
-\end{array}$ & $\begin{array}{l}- \\
- \\
- \\
-\end{array}$ & $\begin{array}{l}- \\
- \\
- \\
- \\
-\end{array}$ & $\begin{array}{l}2 \\
2 \\
- \\
- \\
-\end{array}$ & $\begin{array}{l}- \\
- \\
- \\
-\end{array}$ \\
\hline $\begin{array}{l}\text { W.S. CENTRAL } \\
\text { Ark. } \\
\text { La. } \\
\text { Okla. } \\
\text { Tex. }\end{array}$ & $\begin{array}{r}22 \\
- \\
2 \\
20 \\
-\end{array}$ & $\begin{array}{r}31 \\
- \\
10 \\
20 \\
1\end{array}$ & $\begin{array}{r}549 \\
29 \\
42 \\
73 \\
405\end{array}$ & $\begin{array}{r}970 \\
79 \\
41 \\
129 \\
721\end{array}$ & $\begin{array}{r}280 \\
44 \\
22 \\
36 \\
178\end{array}$ & $\begin{array}{r}395 \\
42 \\
66 \\
54 \\
233\end{array}$ & $\begin{array}{l}- \\
\overline{-} \\
\bar{U}\end{array}$ & $\begin{array}{l}1 \\
- \\
- \\
- \\
1\end{array}$ & $\begin{array}{l}- \\
- \\
- \\
\end{array}$ & $\begin{array}{l}- \\
- \\
- \\
- \\
-\end{array}$ & $\begin{array}{l}1 \\
- \\
- \\
- \\
1\end{array}$ & $\begin{array}{l}- \\
- \\
- \\
-\end{array}$ \\
\hline $\begin{array}{l}\text { MOUNTAIN } \\
\text { Mont. } \\
\text { Idaho } \\
\text { Wyo. } \\
\text { Colo. } \\
\text { N. Mex. } \\
\text { Ariz. } \\
\text { Utah } \\
\text { Nev. }\end{array}$ & $\begin{array}{r}91 \\
- \\
1 \\
4 \\
21 \\
12 \\
43 \\
3 \\
7\end{array}$ & $\begin{array}{r}61 \\
\overline{2} \\
- \\
11 \\
14 \\
28 \\
4 \\
2\end{array}$ & $\begin{array}{r}311 \\
4 \\
28 \\
15 \\
30 \\
10 \\
162 \\
27 \\
35\end{array}$ & $\begin{array}{r}351 \\
1 \\
13 \\
3 \\
75 \\
38 \\
165 \\
26 \\
30\end{array}$ & $\begin{array}{r}231 \\
1 \\
6 \\
16 \\
48 \\
63 \\
69 \\
11 \\
17\end{array}$ & $\begin{array}{r}193 \\
3 \\
4 \\
- \\
35 \\
57 \\
66 \\
10 \\
18\end{array}$ & $\begin{array}{l}\bar{U} \\
\bar{U} \\
\overline{-} \\
\overline{-} \\
\overline{-}\end{array}$ & $\begin{array}{l}- \\
- \\
- \\
- \\
- \\
- \\
- \\
- \\
-\end{array}$ & $\begin{array}{l}\bar{U} \\
\bar{U} \\
- \\
- \\
- \\
-\end{array}$ & $\begin{array}{l}1 \\
- \\
1 \\
- \\
- \\
- \\
- \\
- \\
-\end{array}$ & $\begin{array}{l}1 \\
- \\
1 \\
- \\
- \\
- \\
- \\
- \\
-\end{array}$ & $\begin{array}{l}9 \\
- \\
- \\
- \\
2 \\
- \\
- \\
3 \\
4\end{array}$ \\
\hline $\begin{array}{l}\text { PACIFIC } \\
\text { Wash. } \\
\text { Oreg. } \\
\text { Calif. } \\
\text { Alaska } \\
\text { Hawaii }\end{array}$ & $\begin{array}{r}39 \\
1 \\
11 \\
24 \\
2 \\
1\end{array}$ & $\begin{array}{r}65 \\
3 \\
20 \\
25 \\
1 \\
16\end{array}$ & $\begin{array}{r}817 \\
34 \\
28 \\
743 \\
12 \\
-\end{array}$ & $\begin{array}{r}1,504 \\
127 \\
101 \\
1,259 \\
6 \\
11\end{array}$ & $\begin{array}{r}448 \\
42 \\
18 \\
385 \\
3\end{array}$ & $\begin{array}{r}535 \\
27 \\
43 \\
456 \\
3 \\
6\end{array}$ & $\begin{array}{l}- \\
\overline{-} \\
\end{array}$ & $\begin{array}{l}9 \\
- \\
1 \\
7 \\
- \\
1\end{array}$ & $\begin{array}{l}- \\
\bar{u} \\
\overline{-} \\
-\end{array}$ & $\begin{array}{l}2 \\
- \\
- \\
1 \\
1\end{array}$ & $\begin{array}{r}11 \\
\overline{1} \\
8 \\
- \\
2\end{array}$ & $\begin{array}{r}10 \\
3 \\
- \\
5 \\
1 \\
1\end{array}$ \\
\hline $\begin{array}{l}\text { Guam } \\
\text { P.R. } \\
\text { V.I. } \\
\text { Amer. Samoa } \\
\text { C.N.M.I. }\end{array}$ & $\begin{array}{l}- \\
- \\
- \\
\end{array}$ & $\begin{array}{l}\overline{2} \\
\bar{U} \\
U \\
\end{array}$ & $\begin{array}{l}4 \overline{-} \\
\bar{U} \\
-\end{array}$ & $\begin{array}{r}1 \\
140 \\
\bar{U} \\
U\end{array}$ & $\begin{array}{r}28 \\
\bar{U} \\
17 \\
\end{array}$ & $\begin{array}{r}8 \\
104 \\
\bar{U} \\
U \\
\end{array}$ & $\begin{array}{l}U \\
U \\
U \\
U \\
U\end{array}$ & $\begin{array}{l}- \\
- \\
\bar{U} \\
-\end{array}$ & $\begin{array}{l}U \\
U \\
U \\
U\end{array}$ & $\begin{array}{l}- \\
- \\
\\
-\end{array}$ & $\begin{array}{l}- \\
- \\
- \\
\end{array}$ & $\begin{array}{l}- \\
\\
\\
\end{array}$ \\
\hline
\end{tabular}


TABLE III. (Cont'd) Provisional cases of selected notifiable diseases preventable by vaccination, United States, weeks ending May 26, 2001, and May 27, 2000 (21st Week)

\begin{tabular}{|c|c|c|c|c|c|c|c|c|c|c|c|}
\hline \multirow[b]{2}{*}{ Reporting Area } & \multicolumn{2}{|c|}{$\begin{array}{c}\text { Meningococcal } \\
\text { Disease }\end{array}$} & \multicolumn{3}{|c|}{ Mumps } & \multicolumn{3}{|c|}{ Pertussis } & \multicolumn{3}{|c|}{ Rubella } \\
\hline & $\begin{array}{l}\text { Cum. } \\
2001 \\
\end{array}$ & $\begin{array}{l}\text { Cum. } \\
2000\end{array}$ & 2001 & $\begin{array}{l}\text { Cum. } \\
2001\end{array}$ & $\begin{array}{l}\text { Cum. } \\
2000 \\
\end{array}$ & 2001 & $\begin{array}{l}\text { Cum. } \\
2001 \\
\end{array}$ & $\begin{array}{l}\text { Cum. } \\
2000 \\
\end{array}$ & 2001 & $\begin{array}{l}\text { Cum. } \\
2001 \\
\end{array}$ & $\begin{array}{l}\text { Cum. } \\
2000 \\
\end{array}$ \\
\hline UNITED STATES & 1,111 & 1,100 & 3 & 72 & 169 & 64 & 1,717 & 2,130 & 1 & 6 & 65 \\
\hline $\begin{array}{l}\text { NEW ENGLAND } \\
\text { Maine } \\
\text { N.H. } \\
\text { Vt. } \\
\text { Mass. } \\
\text { R.I. } \\
\text { Conn. }\end{array}$ & $\begin{array}{r}68 \\
1 \\
7 \\
5 \\
38 \\
2 \\
15\end{array}$ & $\begin{array}{r}60 \\
5 \\
4 \\
2 \\
37 \\
3 \\
9\end{array}$ & $\begin{array}{l}- \\
\\
- \\
- \\
- \\
-\end{array}$ & $\begin{array}{l}- \\
- \\
- \\
- \\
- \\
- \\
-\end{array}$ & $\begin{array}{l}2 \\
- \\
- \\
- \\
- \\
1 \\
1\end{array}$ & $\begin{array}{l}1 \\
U \\
- \\
- \\
- \\
-\end{array}$ & $\begin{array}{r}180 \\
- \\
16 \\
22 \\
133 \\
1 \\
8\end{array}$ & $\begin{array}{r}561 \\
12 \\
54 \\
104 \\
361 \\
7 \\
23\end{array}$ & $\begin{array}{l}- \\
\\
- \\
- \\
- \\
-\end{array}$ & $\begin{array}{l}- \\
- \\
- \\
- \\
- \\
-\end{array}$ & $\begin{array}{c}10 \\
- \\
1 \\
- \\
8 \\
- \\
1\end{array}$ \\
\hline $\begin{array}{l}\text { MID. ATLANTIC } \\
\text { Upstate N.Y. } \\
\text { N.Y. City } \\
\text { N.J. } \\
\text { Pa. }\end{array}$ & $\begin{array}{r}83 \\
35 \\
20 \\
23 \\
5\end{array}$ & $\begin{array}{r}104 \\
27 \\
26 \\
22 \\
29\end{array}$ & $\begin{array}{l}- \\
- \\
- \\
\end{array}$ & $\begin{array}{l}2 \\
1 \\
1 \\
- \\
-\end{array}$ & $\begin{array}{r}11 \\
5 \\
3 \\
- \\
3\end{array}$ & $\begin{array}{l}4 \\
4 \\
- \\
- \\
\end{array}$ & $\begin{array}{r}105 \\
89 \\
6 \\
2 \\
8\end{array}$ & $\begin{array}{r}198 \\
95 \\
35 \\
- \\
68\end{array}$ & $\begin{array}{l}- \\
- \\
- \\
\end{array}$ & $\begin{array}{l}1 \\
1 \\
- \\
- \\
-\end{array}$ & $\begin{array}{l}5 \\
1 \\
4 \\
- \\
-\end{array}$ \\
\hline $\begin{array}{l}\text { E.N. CENTRAL } \\
\text { Ohio } \\
\text { Ind. } \\
\text { IIl. } \\
\text { Mich. } \\
\text { Wis. }\end{array}$ & $\begin{array}{r}141 \\
51 \\
24 \\
20 \\
25 \\
21\end{array}$ & $\begin{array}{r}196 \\
40 \\
21 \\
50 \\
62 \\
23\end{array}$ & $\begin{array}{l}- \\
- \\
- \\
\bar{U}\end{array}$ & $\begin{array}{l}9 \\
1 \\
1 \\
6 \\
1 \\
-\end{array}$ & $\begin{array}{r}16 \\
7 \\
- \\
4 \\
4 \\
1\end{array}$ & $\begin{array}{l}6 \\
4 \\
1 \\
1 \\
- \\
\end{array}$ & $\begin{array}{r}206 \\
127 \\
19 \\
23 \\
19 \\
18\end{array}$ & $\begin{array}{r}268 \\
155 \\
22 \\
22 \\
19 \\
50\end{array}$ & $\begin{array}{l}- \\
- \\
- \\
- \\
\end{array}$ & $\begin{array}{l}3 \\
- \\
1 \\
2 \\
- \\
-\end{array}$ & $\begin{array}{l}- \\
- \\
- \\
- \\
-\end{array}$ \\
\hline $\begin{array}{l}\text { W.N. CENTRAL } \\
\text { Minn. } \\
\text { lowa } \\
\text { Mo. } \\
\text { N. Dak. } \\
\text { S. Dak. } \\
\text { Nebr. } \\
\text { Kans. }\end{array}$ & $\begin{array}{r}74 \\
10 \\
18 \\
25 \\
3 \\
4 \\
5 \\
9\end{array}$ & $\begin{array}{r}69 \\
7 \\
16 \\
33 \\
1 \\
4 \\
4 \\
4\end{array}$ & $\begin{array}{l}- \\
- \\
- \\
\\
- \\
-\end{array}$ & $\begin{array}{l}4 \\
1 \\
- \\
- \\
- \\
- \\
1 \\
2\end{array}$ & $\begin{array}{r}10 \\
- \\
5 \\
2 \\
- \\
- \\
1 \\
2\end{array}$ & $\begin{array}{l}2 \\
- \\
- \\
2 \\
U \\
- \\
- \\
-\end{array}$ & $\begin{array}{r}82 \\
17 \\
10 \\
38 \\
- \\
3 \\
2 \\
12\end{array}$ & $\begin{array}{r}86 \\
46 \\
8 \\
14 \\
1 \\
1 \\
3 \\
13\end{array}$ & $\begin{array}{l}- \\
- \\
- \\
\\
- \\
-\end{array}$ & $\begin{array}{l}1 \\
- \\
1 \\
- \\
- \\
- \\
- \\
-\end{array}$ & $\begin{array}{l}1 \\
- \\
- \\
- \\
- \\
1 \\
-\end{array}$ \\
\hline $\begin{array}{l}\text { S. ATLANTIC } \\
\text { Del. } \\
\text { Md. } \\
\text { D.C. } \\
\text { Va. } \\
\text { W. Va. } \\
\text { N.C. } \\
\text { S.C. } \\
\text { Ga. } \\
\text { Fla. }\end{array}$ & $\begin{array}{r}209 \\
27 \\
21 \\
21 \\
4 \\
45 \\
21 \\
30 \\
61\end{array}$ & $\begin{array}{r}156 \\
- \\
16 \\
- \\
28 \\
7 \\
27 \\
13 \\
26 \\
39\end{array}$ & $\begin{array}{l}2 \\
\text { U } \\
- \\
- \\
- \\
1 \\
- \\
- \\
1\end{array}$ & $\begin{array}{r}17 \\
- \\
4 \\
- \\
2 \\
- \\
1 \\
1 \\
7 \\
2\end{array}$ & $\begin{array}{r}24 \\
- \\
5 \\
- \\
4 \\
- \\
3 \\
7 \\
2 \\
3\end{array}$ & $\begin{array}{l}4 \\
\text { U } \\
- \\
- \\
- \\
- \\
3 \\
- \\
- \\
1\end{array}$ & $\begin{array}{r}91 \\
13 \\
1 \\
1 \\
10 \\
1 \\
33 \\
19 \\
3 \\
11\end{array}$ & $\begin{array}{r}157 \\
4 \\
42 \\
- \\
15 \\
- \\
39 \\
16 \\
19 \\
22\end{array}$ & $\begin{array}{l}1 \\
\text { U } \\
- \\
- \\
- \\
- \\
- \\
-\end{array}$ & $\begin{array}{l}1 \\
- \\
- \\
- \\
- \\
- \\
- \\
- \\
1\end{array}$ & $\begin{array}{r}28 \\
- \\
- \\
- \\
- \\
- \\
5 \\
6 \\
- \\
2\end{array}$ \\
\hline $\begin{array}{l}\text { E.S. CENTRAL } \\
\text { Ky. } \\
\text { Tenn. } \\
\text { Ala. } \\
\text { Miss. }\end{array}$ & $\begin{array}{r}79 \\
13 \\
29 \\
30 \\
7\end{array}$ & $\begin{array}{r}77 \\
15 \\
34 \\
22 \\
6\end{array}$ & $\begin{array}{l}- \\
- \\
- \\
\end{array}$ & $\begin{array}{l}1 \\
1 \\
- \\
- \\
-\end{array}$ & $\begin{array}{l}4 \\
- \\
2 \\
2 \\
-\end{array}$ & $\begin{array}{l}1 \\
- \\
- \\
1 \\
U\end{array}$ & $\begin{array}{r}40 \\
11 \\
17 \\
9 \\
3\end{array}$ & $\begin{array}{r}43 \\
25 \\
7 \\
8 \\
3\end{array}$ & $\begin{array}{l}- \\
- \\
- \\
\end{array}$ & $\begin{array}{l}- \\
- \\
- \\
-\end{array}$ & $\begin{array}{l}4 \\
1 \\
- \\
3 \\
-\end{array}$ \\
\hline $\begin{array}{l}\text { W.S. CENTRAL } \\
\text { Ark. } \\
\text { La. } \\
\text { Okla. } \\
\text { Tex. }\end{array}$ & $\begin{array}{r}160 \\
10 \\
52 \\
18 \\
80\end{array}$ & $\begin{array}{r}128 \\
6 \\
33 \\
19 \\
70\end{array}$ & $\begin{array}{l}- \\
- \\
- \\
-\end{array}$ & $\begin{array}{l}7 \\
1 \\
2 \\
- \\
4\end{array}$ & $\begin{array}{r}20 \\
1 \\
4 \\
- \\
15\end{array}$ & $\begin{array}{l}- \\
- \\
- \\
\end{array}$ & $\begin{array}{r}53 \\
3 \\
1 \\
1 \\
48\end{array}$ & $\begin{array}{r}85 \\
10 \\
6 \\
9 \\
60\end{array}$ & $\begin{array}{l}- \\
- \\
- \\
\end{array}$ & $\begin{array}{l}- \\
- \\
- \\
-\end{array}$ & $\begin{array}{l}6 \\
1 \\
1 \\
- \\
4\end{array}$ \\
\hline $\begin{array}{l}\text { MOUNTAIN } \\
\text { Mont. } \\
\text { Idaho } \\
\text { Wyo. } \\
\text { Colo. } \\
\text { N. Mex. } \\
\text { Ariz. } \\
\text { Utah } \\
\text { Nev. }\end{array}$ & $\begin{array}{r}57 \\
- \\
5 \\
1 \\
23 \\
8 \\
11 \\
5 \\
4\end{array}$ & $\begin{array}{r}52 \\
1 \\
6 \\
- \\
14 \\
6 \\
17 \\
6 \\
2\end{array}$ & $\begin{array}{l}1 \\
U \\
- \\
\\
- \\
\overline{1} \\
- \\
-\end{array}$ & $\begin{array}{l}7 \\
- \\
1 \\
1 \\
1 \\
2 \\
1 \\
- \\
1\end{array}$ & $\begin{array}{r}13 \\
1 \\
- \\
1 \\
- \\
1 \\
3 \\
4 \\
3\end{array}$ & $\begin{array}{r}44 \\
U \\
1 \\
U \\
5 \\
- \\
38 \\
- \\
-\end{array}$ & $\begin{array}{r}828 \\
6 \\
161 \\
1 \\
140 \\
49 \\
453 \\
13 \\
5\end{array}$ & $\begin{array}{r}331 \\
7 \\
39 \\
- \\
188 \\
54 \\
30 \\
9 \\
4\end{array}$ & $\begin{array}{l}\bar{U} \\
\bar{U} \\
- \\
- \\
- \\
-\end{array}$ & $\begin{array}{l}- \\
- \\
- \\
- \\
- \\
- \\
- \\
-\end{array}$ & $\begin{array}{l}1 \\
- \\
- \\
- \\
1 \\
- \\
- \\
-\end{array}$ \\
\hline $\begin{array}{l}\text { PACIFIC } \\
\text { Wash. } \\
\text { Oreg. } \\
\text { Calif. } \\
\text { Alaska } \\
\text { Hawaii }\end{array}$ & $\begin{array}{r}240 \\
38 \\
17 \\
181 \\
2 \\
2\end{array}$ & $\begin{array}{r}258 \\
23 \\
29 \\
195 \\
3 \\
8\end{array}$ & $\begin{array}{l}- \\
\bar{N} \\
\mathrm{U} \\
-\end{array}$ & $\begin{array}{r}25 \\
\bar{N} \\
20 \\
1 \\
4\end{array}$ & $\begin{array}{r}69 \\
2 \\
N \\
58 \\
4 \\
5\end{array}$ & $\begin{array}{l}2 \\
- \\
2 \\
U \\
- \\
-\end{array}$ & $\begin{array}{r}132 \\
40 \\
9 \\
83 \\
- \\
-\end{array}$ & $\begin{array}{r}401 \\
116 \\
38 \\
222 \\
5 \\
20\end{array}$ & $\begin{array}{l}- \\
- \\
\\
- \\
-\end{array}$ & $\begin{array}{l}- \\
- \\
- \\
- \\
-\end{array}$ & $\begin{array}{r}10 \\
7 \\
- \\
3 \\
- \\
-\end{array}$ \\
\hline $\begin{array}{l}\text { Guam } \\
\text { P.R. } \\
\text { V.I. } \\
\text { Amer. Samoa } \\
\text { C.N.M.I. }\end{array}$ & $\begin{array}{l}\overline{1} \\
\bar{U} \\
-\end{array}$ & $\begin{array}{c}\overline{5} \\
\bar{U} \\
U\end{array}$ & $\begin{array}{l}U \\
U \\
U \\
U \\
U\end{array}$ & $\begin{array}{l}- \\
\bar{U} \\
-\end{array}$ & $\begin{array}{l}3 \\
- \\
- \\
U \\
U\end{array}$ & $\begin{array}{l}U \\
U \\
U \\
U \\
U\end{array}$ & $\begin{array}{c}- \\
- \\
\bar{U} \\
-\end{array}$ & $\begin{array}{r}2 \\
1 \\
- \\
U\end{array}$ & $\begin{array}{l}U \\
U \\
U \\
U \\
U\end{array}$ & $\begin{array}{l}- \\
- \\
\bar{U}\end{array}$ & $\begin{array}{c}1 \\
- \\
- \\
U\end{array}$ \\
\hline
\end{tabular}

$\mathrm{N}:$ Not notifiable.

U: Unavailable.

-: No reported cases. 
TABLE IV. Deaths in 122 U.S. cities, ${ }^{*}$ week ending May 26, 2001 (21st Week)

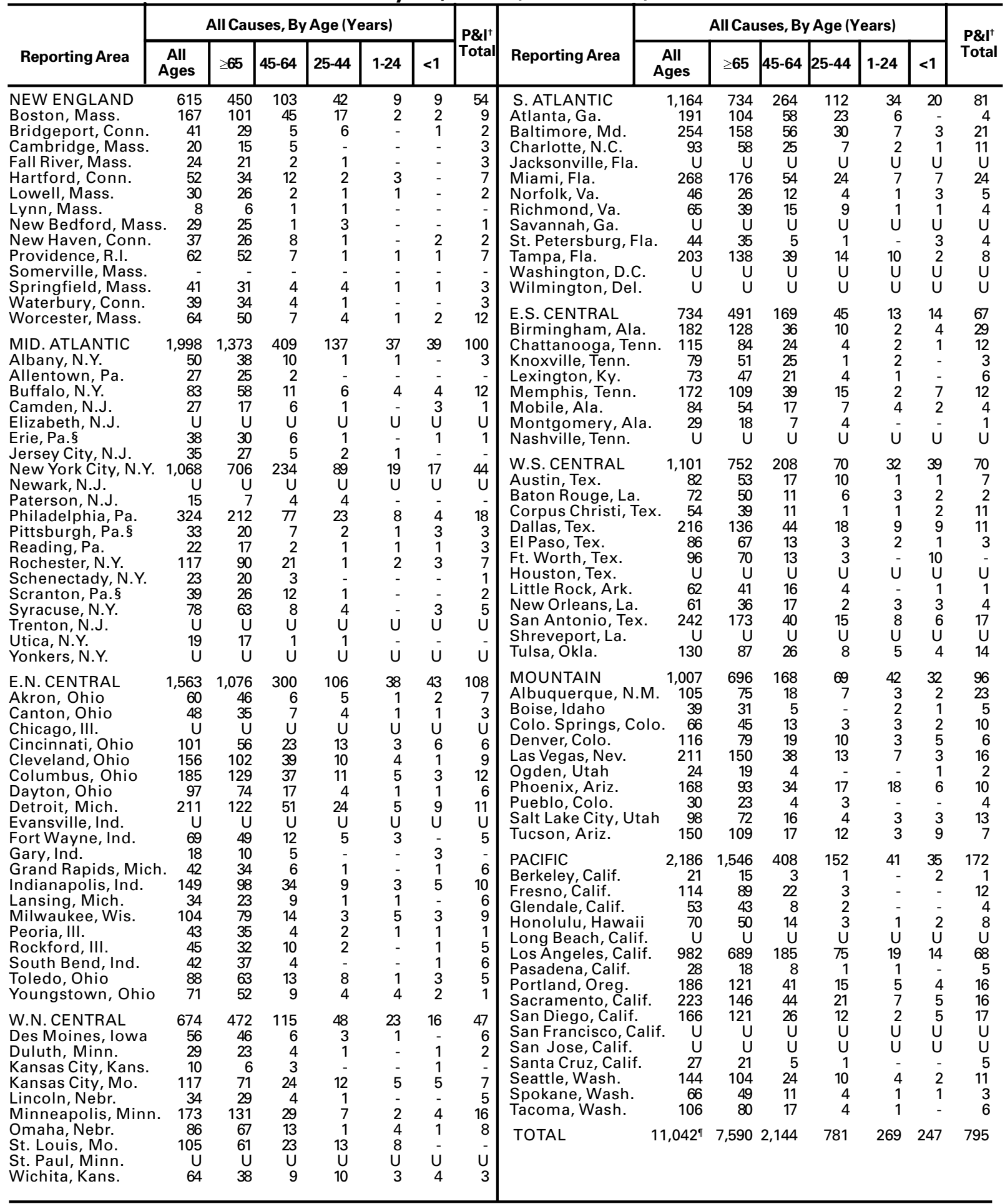

U: Unavailable. -:No reported cases.

* Mortality data in this table are voluntarily reported from 122 cities in the United States, most of which have populations of $\geq 100,000$. A death is reported by the place of its occurrence and by the week that the death certificate was filed. Fetal deaths are not included.

tPneumonia and influenza.

${ }^{\S}$ Because of changes in reporting methods in this Pennsylvania city, these numbers are partial counts for the current week. Complete counts will be available in 4 to 6 weeks.

iTotal includes unknown ages. 


\section{Contributors to the Production of the MMWR (Weekly)}

Weekly Notifiable Disease Morbidity Data and 122 Cities Mortality Data

Samuel L. Groseclose, D.V.M., M.P.H.

State Support Team

Robert Fagan

Jose Aponte

Gerald Jones

David Nitschke

Scott Noldy

Carol A. Worsham
CDC Operations Team

Carol M. Knowles

Deborah A. Adams

Willie J. Anderson

Patsy A. Hall

Suzette A. Park

Felicia J. Perry

Pearl Sharp

Informatics

T. Demetri Vacalis, Ph.D. 
The Morbidity and Mortality Weekly Report (MMWR) Series is prepared by the Centers for Disease Control and Prevention (CDC) and is available free of charge in electronic format and on a paid subscription basis for paper copy. To receive an electronic copy on Friday of each week, send an e-mail message to listserv@listserv.cdc.gov. The body content should read SUBscribe mmwr-toc. Electronic copy also is available from CDC's World-Wide Web server at http://www.cdc.gov/mmwr or from CDC's file transfer protocol server at ftp://ftp.cdc.gov/pub/ Publications/mmwr. To subscribe for paper copy, contact Superintendent of Documents, U.S. Government Printing Office, Washington, DC 20402; telephone (202) 512-1800.

Data in the weekly MMWR are provisional, based on weekly reports to CDC by state health departments. The reporting week concludes at close of business on Friday; compiled data on a national basis are officially released to the public on the following Friday. Address inquiries about the MMWR Series, including material to be considered for publication, to: Editor, MMWR Series, Mailstop C-08, CDC, 1600 Clifton Rd., N.E., Atlanta, GA 30333; telephone (888) 232-3228.

All material in the MMWR Series is in the public domain and may be used and reprinted without permission; citation as to source, however, is appreciated.

Director, Centers for Disease

Control and Prevention

Jeffrey P. Koplan, M.D., M.P.H.

Deputy Director for Science and

Public Health, Centers for Disease

Control and Prevention

David W. Fleming, M.D.
Director,

Epidemiology Program Office

Stephen B. Thacker, M.D., M.Sc.

Editor, MMWR Series

John W. Ward, M.D.
Acting Managing Editor, MMWR (Weekly)

Teresa F. Rutledge

Writers-Editors, MMWR (Weekly)

Jill Crane

David C. Johnson

Desktop Publishing

Lynda G. Cupell

Morie M. Higgins

U.S. Government Printing Office: 2001-633-173/48234 Region IV 